University of Louisville

ThinkIR: The University of Louisville's Institutional Repository

Electronic Theses and Dissertations

1939

\title{
Correlation of cooling data for kerosene.
}

James Franklyn Scott

University of Louisville

Follow this and additional works at: https://ir.library.louisville.edu/etd

Part of the Chemical Engineering Commons

\section{Recommended Citation}

Scott, James Franklyn, "Correlation of cooling data for kerosene." (1939). Electronic Theses and Dissertations. Paper 1896.

https://doi.org/10.18297/etd/1896

This Master's Thesis is brought to you for free and open access by ThinkIR: The University of Louisville's Institutional Repository. It has been accepted for inclusion in Electronic Theses and Dissertations by an authorized administrator of ThinkIR: The University of Louisville's Institutional Repository. This title appears here courtesy of the author, who has retained all other copyrights. For more information, please contact thinkir@louisville.edu. 


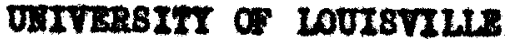

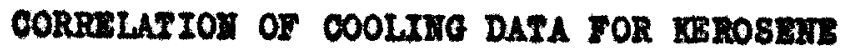
11

\author{
A Thest: \\ Submittod to the Faoulty \\ of the Gradute Sohool \\ of the Ondreresty of Louterdile \\ in Partiel Pulp12inont of the \\ Requiroments for the Degree of \\ MABTER OP CHEMITAL BHOTHEERTHO
}

Dopartwont of Chondoal Bugineorlns

by

Jane Prandyra Soott

111

198 


\section{JAYES TRAMLITE SOORT}

\section{CORRELATIOI OF COOLIMO DATA FOR KEROBEMS}

Approved by Exunining Comittee,

Direotor:


Approved for anglith

Dete: Jumo 6, 1939 


\section{FADLE OP COATwins}

\begin{tabular}{|c|c|}
\hline & Page \\
\hline LIST OF TABLES & $\nabla$ \\
\hline LISI OP PIGURES & $\mathbf{v}$ \\
\hline TABLE OF HOMENCLATURD & $\nabla$ \\
\hline SCTHOWLEDAMEY & $\mathbf{7 1 1}$ \\
\hline IHeroDoctrox & 1 \\
\hline BISTORICAL & 3 \\
\hline THEORETICAL & 14 \\
\hline BTPERTMBARAL. & 26 \\
\hline Apparatus & 27 \\
\hline Operation & 33 \\
\hline Test Prosedure & 34 \\
\hline Phyclaal Propert1es & 36 \\
\hline Date & 42 \\
\hline REsULAS AND concLostons & 60 \\
\hline BIBLIOQRAPHT & 68 \\
\hline
\end{tabular}


LIST OF TABLES

Page

TABLES

I Englor D1otillation Rango of Eooono 37

II Heat Iranefor Date 44

\section{LISE OF FICURES}

\section{TIGURE8}

1 Heat Exahanger 30

8 Skatoh of Apparatue 81

3 Bffeot of Temperature on V1scosity 38

4 8peelfio Heat at remperatures of $-20-140 \%$. 40

6 Effeot of romperature on speolflo ararity 41

6 Dittua and Booltor Corrolation of Booeno Data 52

7 Corrolation of Roynolds Number v8, Nuscelt 54

Number for zooone Date.

8 Triotion Factor - Reynold Number Curve 66

- Cooling Corrolation of Friotion Faotor ve. Iusselt number for Kerosene 57

10 cooling Correlation of Friotion Faotor ve. Nused It number for 01Ls 58

21 Heating Corrolation of Friotion Fuotor ro. nueselt number for 0lis

12 Correlation of Heating and cooling costriolunts 
TABLE OF HOMEHCLATURS
$\Lambda$ = Heat transfor aurface
aq. It.
c = speolf10 hoat at oonstant proceuro
B.T.0./(1b.) $\left({ }^{0}.\right)$
D Inolde liawoter of tube
ft.
$P=$ Friotion Iactor in Fanning equation
$\Delta \mathrm{H}=\frac{\text { zf L } \psi^{2}}{\mathrm{~g}^{\mathrm{D}}}$
B - Aocoleration due to gravity
$4.16 \times 10 \mathrm{ft} . /(\mathrm{hr} .)^{2}$
0 Inae Ve1001ty
$\# /($ hr. $)\left(\mu_{0}\right)^{2}$
h = Average surface coefflelent of hoat tranafer between tube surfeos and Sluid
$B . T \cdot D_{\cdot} /(\mathrm{hr} \cdot)(\mathrm{ft})^{2}\left({ }^{\mathrm{O}} \mathrm{F}\right)$
$\Delta B=$ Drop in fluid hoad dwo to friotion
to.
$x=$ Thormal oonduotirity
$B . T \cdot 0 .-r t /(h r)(\rho t)^{2}\left(o_{T}\right)$
$L$ Heated length of tube
st.
$x$ unes
2bs.
$Q=$ Quantity of hoat trancforrod
B.T.0./hr.
$r$ - Factor in Prandt I equation
t - Tomperature differenoe (in disoussion of dimensions)
P.
$t_{1}=$ Average teroperature of fluld ontorlng test seotion
P.
$t_{2}=$ Average outlet temperature of fluld
\%.
$I_{1}=$ Arerage tube temparature at lalot and
?.
$I_{2}=$ Arerago tube temperature at outlot and
s.
a = Average fluld veloolty
It. $/ \mathrm{hr}$. 


$$
\begin{aligned}
& \nabla=\text { Oporall soofflotent } \\
& B .5 .0 \cdot /(h r)(f t)^{2}(9 p) \\
& \text { W Wolght rate of slew } 2 \mathrm{bs} . \mathrm{hr} \text {. } \\
& \Delta t=\text { Temperature riee of fluid }{ }^{\circ} \text {. } \\
& \Delta T=\text { Arlthmeleal tomperature differenos op. } \\
& \text { In } \Delta T=\text { Log moan tomporature differenee } \\
& \text { Irom motal surface to rluid } \\
& \rho=\text { Density of rluid } \\
& \text { - Vieoostty of eluid at minentream } \\
& \text { tomperature } \\
& \text { F. } \\
& \text { 2bs./ou. ft. } \\
& \text { Centipolsen } \\
& \mu=\text { Viscosity of Pluid at moln-atroam } \\
& \text { tomporature } \\
& 1 b s /(f t)(h r) \\
& \mu=V 1 \text { coosity of Fluid at moan film } \\
& \text { temperature } \\
& 2 b=/(\mu t)(h r) \\
& \mu \text { vineostty of rluid at temporature } \\
& \text { of Innor tube surface } \\
& 1 b_{8} /(\mathrm{rt})(\mathrm{hr}) \\
& \phi=T \ln
\end{aligned}
$$

subeer1pts:

h. = Ropresonts oondition of heating and cooling

Symbole are frem the oyetom reoomended by the Counoll of Amorlone Inotitute of Chomieal ingineers. 


\section{ACXNOTLDOAEXK}


The author of this thests wishos to nolmomledge the assistanes, euggent10ns, and oritiolome of Dr. R, C. Irnst, who direoted this research. 
Intropoct IOU 


\section{IRARODUCXIOX}

The purpose of this Imvertigation was to otudy the beharlor of the coofflolent of hoat transfor under conditions


and lewer turbulent conditione was obtainod. I hydrosarbon 011, a purifled watermbite keroson known as Booen, was ueod in this oxperimental work.

The exporiwntal date was obtalnod in a horisontal doublemtube heat exohanger haring a ix foot test soation and uelns a ono lnoh brate plpo. Bocene was alwo used for a ooolIns modium,

Liquid tomporatures ranglng from $60^{\circ}$ to $20^{\circ} \mathrm{F}$. covered a temperature region not previously imvotigated. Liquid rates of flow oovered a range of Reynolds numbers of from 10 to 13,000 .

The prinolple of dimonalonal analysis was used in an attempt to obtain a oorrelation of various groups. The Dittus and Boolter equation and others wore oompared. A oorrelation of Juscelt numbers versus eriotion faotors gave entlafactory reoulte with this and other experimentel data. 
BISTORICAL 
HISTORICAL

- Oeborne Roynolde(27) in 1874 prodioted an analog botweon hoat tranemianion and fluld friotion. Ho proposed the dimonolonless equation

$$
h=r 0_{p} \theta / 2
$$

rolating the heat tranafor ooefflolent with the drop in proserure due to fluld friotion. The Reynolds analog prosupposes that all the thermal realetanoe is in the fluld core.

In 1856 Graets (20), ansuning hoat tranofor to a fluld in Fisoous flow was by conduotion only, obtained the relation:

$$
\left(t_{2}-t_{1}\right) /\left(T-t_{1}\right)=1-6 P_{2}
$$

where $P_{2}$ reprecents the convergent infinite series.

$$
P_{2}=0.20238^{-14.6272 n}+0.01220^{-89.22 n}+0.002370^{-212 n}+\ldots
$$

and $n=k L / 4 W \theta_{p}$. Thls latter group is the so-oalled oraets number whioh has boen oorrelated by other exporimenters. The oquation does not 1nvolve tho ooefflolont of hoat transfor. In 1900 iruacelt ${ }^{(25)}$ applied the prinolple of dimen- Lomal elmlarity and obtalned hie woll-kmown genoral equation for turbulent flow in plpos,

$$
h D / x=\phi(D O / \mu) \phi^{\prime}(0 \mu / k) \phi^{\prime \prime}(D / L)
$$


Aseuning hoat transfor by oonduotion and convootion to be oontrolied by the faotors entering the differential oquations for both hydrodymates and heat conduotion. Museelt suggested that the Introduation of the term $D / L$, the ratio of the diamoter to the heated length, would affeot the oorrelation of the equation. In 1010 luseolt remalseovered the equation proposed by Graots for the hoat trancfor of 11 quids in Visooun flow. Pranat ${ }^{(26)}$, 10 2910, baced his analogy on the ascumption that part of the thermal resiatanoe is in the oore. and the remindor in a f12n flowing in Fisoous motion along the plpe well. He proposed the equation:

$$
h=\left(r 0_{p} \theta / 2\right) /(1-r)+r\left(0_{p} p_{p} / x_{f}\right)
$$

where $r\left(o_{p}{ }_{p} / k_{p}\right)$ is the thermal resietanoe of the $f 11 \mathrm{~m}$ and $(2$ - r) that of the oore.

MoAdam and Proot (21), In 1922, disousaed the rolation between hoat tranafor and fluld friotion and proposed a smplifled fors of the Iusselt equation for the $121 \mathrm{~m}$ ooerflotent of hoat transfer for flulds clowing inside pipes in turbulent motion. They gave the equation:

$$
\mathrm{h}=22.6 \quad \mathrm{k} / \mathrm{D}(\mathrm{DQ} / \mu)^{.796}
$$

-btalnad from the plot of $h D / k \nabla 8 . D C / \mu$ using exporimntal data for water from four souroes and data for 11ght 0118 from two courees. 
Rleo (28) rooaloulated the date of pereral investigators for both hoating and oooling of water and ollo and suggested the oquations

$$
\mathrm{hD} / \mathrm{K}_{\mathrm{f}}=1 / 60\left(\mathrm{Du} \mu_{\mathrm{f}} / \mu_{\mathrm{f}}\right)^{0.83}\left(\mathrm{c}_{\mathrm{f}} \mu_{\mathrm{f}} / \mathrm{K}_{\mathrm{f}}\right)^{0.5}
$$

Morris and mitman ${ }^{(23)}$ correlated data oovering heatInf and oooling of three potroloum olls and water in horison. tal steel plpe. They ovaluated the physioel properties of the 11quids at the rilm temporature and found that the cooling data valus were more than double those for heating. The date were recaloulated on in stream temperatures in the final oorrelat10n. These data plotted aveording to the Muselt oo-ordinates did not form straight line but were of the forms

$$
y=(\mathrm{hb} / \mathrm{c})(c \mu / \mathrm{c})^{0.37} \text { vs. } \mathrm{DQ} / \mu
$$

They axggected that for oooling a ralue of $78 \%$ of the hoating ralues be used.

In 1930 Dittue and Boelter(6) noted the date for both heating and 000 ing of flutds in the region of turbulent flow oould be oorrelated the equations

$$
n D / x=0.023 \quad(D 0 / \mu)^{0.8} \quad(c \mu / x)^{m}
$$

where is .4 for hoating and .3 for oooling.

$$
\text { Lawronee and sherwood }(18) \text { reported data on hoatlins }
$$

water in rour length of pipe. They correlated these date ustng the equation:

$$
h D / c=480(D a / \mu)^{0.7}(\mathrm{c \mu} / \mathrm{k})^{0.5}
$$


and conoluded that although the length of pipe rarled from 58 to 224 diamotera, the offoot of the longth wa nogligible. They plotted the date of a nuber of inrestigators uoling the mothed propesed by $\mathrm{Z} . \mathrm{E}$. W1Ison in which the reolprosals of the overall oceffiolent o 18 plotted agalnet $0.24 / \mathrm{r}^{0.73}$. The slope of the line oubstentiates the oonolusien of noglectIng the tube length for equations in the region of trubulont 210.

Drw. Hogan; and MoAdans (8) prosented date of Holdon

and mite $(34)$ for heating a hydrooarbon oll plowing in a atroam Iine motion in a horisontal ooppor pipe. The data, when plotted as required by the Crects theory, gare a swooth ourve of the required shape. However, the empirioal ourre oalls for subctantially groater heatlng than the theory based on parabolie dietribution of mes relooity. Additional dati from the ILterature gave results of the anse ordor of magaltude, although oooling rume fall belom hoating data. The data plotted with the $(\mathrm{DO} / \mu)$ replaoing the Group $(\mathrm{Ho} / \mathrm{KL})$ as absolsese showed that for stream-1ine flow the une of the comordinates Wo/kl is preferable to the Reynolde number. K1ribride and Lecabe $(17)$ reported data on the tranefor of hoat to liquide flowing at veloolties below the 180 thermal oritioal reloolty. They correlated thelr data an 
those of Yorrte(22) and Yorris and whitman $(23)$ by the NueseltOrober theory which oxprocese the flim ooofflolont in the form

$$
h D / k=\left(k l / p^{2} v_{c}\right)
$$

The theory correlated the data from the three cources representing a range of 7 soosity of from 0.6 to 50 oentipoleos although the co-ordinaten do not lnolude a Msoosity term, Thoy suggected a general oorrolation of date for both riwoous and turbulont flow uning the equation:

$$
h D / K=f(k / O O D, D Q / z, L / D)
$$

shormood, IIloy and langeon ${ }^{(30)}$ found the offeot of the length of the pipe was nogliglble in the correlation of thoir dati for hoating of hydrooarbon oll in turbulent $110 \mathrm{n}$ through eovoral different lengthe of hor 1sontel eopper plpo. Thoy plotted date uaing the oo-ordinntes eucgested by Morris and Whitman ${ }^{(23)}$ and obtalned a ourve roughly paralleling that of Morris and Mnltman, but comowhat lower. For raluse of $(D Q / \mu)$ below 2,000, the polnts wore widely soattered although a rough oorrelation was obtained for each indiridual tube 20ngth. They reported that although a reasomably mooth ourve was obtainod above the oritioal point, the Morrle and Whitman oomordinates were oloarly inadequate for the oorreletion of the data in the Heoous slow recion. 
Drow (8) hated glyoorol in a horisontal pipe in rlsoous flow and plotted his rebults ualng the nothod of Drow. Hogan, and Wohdams $(\theta)$. The $11 \mathrm{mit}$ ted amount of data made It impoesible to determine genoral oorrelation of the Ilecou region of flow. Drww suggented that the mothod of plotting:

$$
\left(t_{2}-t_{1}\right) /\left(x-t_{2}\right) \text { r. } \mathrm{wc} / \mathrm{aL}
$$

1s Inadoqute whon date on different 11quide wore conuldored and probably umeatiafactory whon own the sume 11 quid was hand2ed at differont temporature levels.

Lawronos and Bogan (19) in proecuting date using tho Prandt-Taylor equation, conoluded that this wathod ald not provide oufflolont cerreletion. Thoy reocumended oorrelation

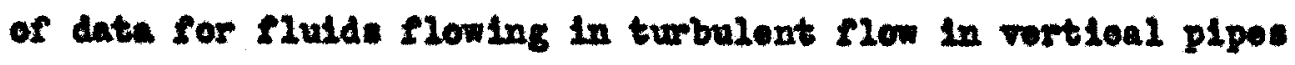
by moane of the DLttus and Boolter equations. Shorwood and Potrio(29) presonted date on hat trensmestion to water, acetone, bonkene, kerosone, and n-Butyl aloohol flowing in risoous and turbulent flow through a horisontel eopper plpe. The data obtalned in the turbulent region were fornd to be well correlated by the Dittue and Boeltor equation

$$
h D / k=0.024(D 0 / \mu)^{0.80}(c \mu / x)^{0.40}
$$

Thole rosults indleating that the elope of the ourve for leerosene was dorinitely prontor at veloodties 1 to 10 thwe tho oritioal than for othor 11quide my be oompared with data of Morris and 
Thitmon (28) and of sherwood, K11ey and ungeen $(30)$ who obtalnod elmilar results with other potroloum olls. Tholr results Indleated that the equation of Dittue and Booltor is olourly wrellable when applied to risoous flom.

Cryder and a1112and (5) in the heating of difforent IIquide disoovered that a dimenelcenily sound equation, reprom aoxting the dath for all 11quide used in these oxporiments. whe not obtalnable without the nes of rariable aurface tonsion. Ther plottod tholr date using on oquation whioh bot oorrolated the valus howover, this equation was not dimonsionlese. Lurphree (24) presented a mothod of enloulating hent trancfer coefflotents for fluld flowing in pipes in turbulont motion from oxloting date on plpe friotion and veloolty dism tribution. The method, If applieable only to oases where the temperature gradient, is onoh that the physloal propartios of the eluid do not appreclably vary aorose the plpe orose cootion. The caloulated eoerflolents are compared with published exper1wontal reaults on gaces, water, and oll. The oorrelation

$$
\mathrm{hD} / \mathrm{k} \text { ra. }\left(\mathrm{s}_{t} / \mathrm{s}_{\mathrm{c}}\right)\left(\mathrm{DC} / \mu_{\mathrm{f}}\right)
$$

where $f_{t}$ is the friotion fector for the tube in question and 1. Is the frlotien factor for the oopper tube, resulted in sopatete ourves for the group $(c \mu / x)$. 
Inye and Furnad (15) advanoed atheory to expleln

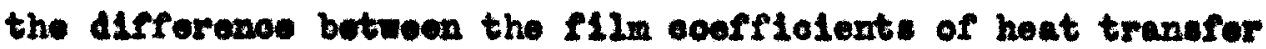
on hoating and o001ing fluids in turbulent flow in oontact With solid surfsces. Thoy baced thoir assumptions on the bow havior of the 11quid f1lm boundary and aggented the relations

$$
h_{0} / h_{h}=\left(\mu_{b} / \mu_{0}\right)^{a}
$$

whore $a=n / m$, oonetant oraluatod by trial. Thls ocmatant wae found ompirloally to be beat taken as 0.6. The corrolation requires ovaluation of the data on the baste of the moen f1im temperature. Hoating or ooollng ooefficlents may be obtained whon date only for the opposite oase are known. J.F. Downie sulth(32) correlated date on hoating and 000 ing of an o11 in risoous and turbulent flow in a horlsontal ooppor plpo. Ho notod olose agreoment with data of other Inventigatore for turbulent flow data whon plotted with the Dittus and Boolter comordinates,

$$
(\mathrm{hD} / \mathrm{x}) /(0 \mu / \mathrm{k})^{\mathrm{n}} \text { rs. }(\mathrm{DC} / \mu)
$$

whore $n=0.3$ for cooling and 0.4 for heating. In viseous Ilew, the pointe showed no saticfactory correlation although exoellent ourves would result if $n$ were oraluated for heatIng $=0.21$ and for o0011ng $=-0.21$. He plotted $t_{1}-t_{2} / t_{1}-t_{1}$ and ho/k as ordinates and Wo/lel as abselsene and obtalnod 
agreanont of the eame ordor of mgatude as previously obtalnod. Distinot ourres ooourred for definite temperature Alfrerenoes of tube and o11.

$$
\text { Jurgeneen, Jr. and ront1211 on (14) heated water in }
$$

an Inolined plpo and pletted.

$$
(\mathrm{hD} / \mathrm{x}) /(\theta \mu / \mathrm{c})^{0.4} \text { re. } \mathrm{De} / \mu
$$

obtalning good oorrejation of thoir data. In the horisontal poettion, the date were compared whth equations recomended by Lamronee and Sherwood $(18)$, and DLttus and Boelter (6). The alope of the Lawrenoe and Sherwood line is ohooked alnost exectly, however, the data fall distinotly above those three 11nes. The date indloated that bigher coefflolents wore obo talnod bolow a Roymolds number of 20,000 for downard flem than thoce for horlzontal pipee, while upward flow rosulted In lemer coefriolents than those for horisontal plpes. Thoy ouggorted thet the effeot of thermal flow in relation to ocervotion wixing in the fluld strean mo rosponstble. sleder and Tato (31) provented date on heat tranaror to three olis of widdy different temperature ooefflolente of Iscosity in risoous flow in a tube for both heating and o0011ng. The reaults are correlated in terme of the main-otreas flutd preperties by a method which takes into asoount the Iseost by gradlent of the fluid in the tube. The date for 
both heating and oooling wore brought into agreomont. Additional data from the 11terature also correlated woll on this balle. Thoy plottods

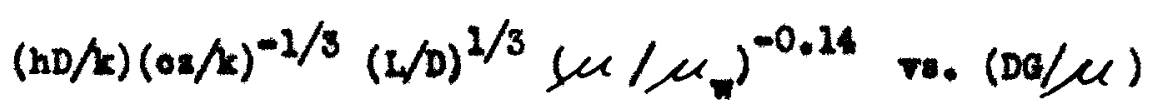

and obtalned atralght 21 ne in the risoous reglon. They pointed out that when donling with 21quids with mall tom perature cooffloionte of viscosity, the $\mu / \mu_{v}$ Eroup row quires aupplomontation by the addition of the Orachor eroup. The datic of Drow ${ }^{(8)}$ sor hoating of glyoerol in riseous flow wore brought into agreament whon plotted with these comordinates. Thi" mothod whowe definite ourves for the ratio of $L / D$ in the Tisoous region. The offoct tapers off through the oritioal region and disappoare ontirely in turbulont flow. Browne and Fingor $(3)$ and Donahem $(7)$ dealgoed and oonotruoted the hoat exohanger ueed in this investigation. PreVlous experimental work of aroth(21) and Barnes(2) oooling kerovene in a horisontal one inch pipe was oorrelated by the Dittus and Boelter equation using the Prandtl group as the 0.3 powor. Thece date were predominatoly in the oritioal reglon. The slope of the line best representing their date was ereater than 0.8 . They abtained the oquation:

$$
h=k / D(0 \mu / x)^{\cdot 3} \quad(D G / \mu)
$$

The data wore considerably soattered in the rasous roglon. The values of the hout tranufer coefflolent wero higher than obtalned by othor Investi gators. 
THEORERTCA. 


\section{THEORETICAL}

Flulds flowing through p1pos in 1sothermal flow are gonorally oonsidered as possessing elther of two types of motion. If the veloolty is low, stream-1ine or Fisoous flow ocours wh1le for greator relocitios turbulent flow exists. In 1sothormal flow of flulds at low voloolties, the fluid has boen assumod to hare a parabollo reloolty gradient aoross the tube soetion. Th1s parabolio gradiont ohanges logarithmically as the sluid passes into turbulent flow. A region exists betwoen turbulent and Neoous flow in which olther Flsoous or turbulent flow may predominate depending on rarlous variables. The type of flow whioh will prodominate in this region is probably a funotion of the past hlstory of the fluid stream.

varlous investigators have oorrelated the mass rate of flow of fluids in the form of almoneionless group with the fluid friotion. In the risoous and turbulent rogions this mothod of oorrolation has roultod in woll establlshod ourve for fluid flowing undor lsothormal oonditions. The relation between the friotion faotor and the Reynolds number which is a oriteria of the type of flow existing in a pipe has not been as definitely eatablished at the lower oritioul region. 
Onder conditions in whioh heat is transferred to a 11quid body flowing through pipes, a distortion of the type or flow ooours. This has been attributed to oonrootion ourrents introduoed by the temperature gradient.

The tranafer of heat produees a temperature gradient aoross the Ilquid stream whioh oauses conveation ourrents to be set up perpendloular to the mass roloolty of flow. Colburn suggested the term "thermal flow" as epplying to the oonveotion ourrents, or oddy effocts sot up In the fluid stroam duo to a tomporature gradient. The gnitude of this thermal flow is undoubtedly a funotion of the temperature gradiont existing aoross the tube sotion. Also, the effect of these conveotion ourrents w11l be of greater magitude in the 1sothermal viscous region than in the turbulent region.

The theoretical oquations proposed by Reynolds wero based on the ascumption that the resiotanos to heat transfor coourred entirely in the fluid oore. vusselt, in modifyIng Reynolds original analogy botwoen fluid friotion and hoat trancfor assued that part of this resiotanoe oocurrod in a Platitious FIIm at the tube wall. Oraets's theoretioal analogy for flulde flowing in visoous motion 18 based on the assumption that heat is tranaferred through the fluid atream entirely by oonduotion. Lator Inventigators have attempted oorrelations 
of their date along 11 nes proposed by these early thoorles. These inteatigators have made use of the original theory of a otagant or Heoous f1Im existing at the tube wall. In most cases they have considered this f1Im the oontrolling faotor in the tranomiseion of heat. Considerable substantiation of this assumption exiats sinoe the coeffiolent of heat transfer definitely inoreases as some fuotion of the mase rate of $110 w$. Inoreasing the veloolty of flow inoreases the frlotional resistance at the surface of the $111 \mathrm{~m}$. A deorense in the $112 \mathrm{~m}$ thloknoss occurs by actual romoval of the moleoules of the film.

Some Invostigatora have attaoked the problem from a rgorous mathomationl viowpoint in an attempt to derelop an equation whioh tabes into woount the offeots produced by this typo of eddy 120w. These attempts have falled to solve the problem and at best hav rosulted in indiridual corrolation of dath or groups of data. Thermal 1 low is a funotion of the vicoosity. density, ooeffloient of thermal oonduotivity, ooefflolont of thermal expansion, and gravitational effeot, and therefore might be expected to be function of the Ilquid omploged and temperature gradiont. Correlations whioh are of an ompletonl nature usually serve to fit some investigators' data for eintiar conditions and 21quids, but, ad whole, do 
not provide a general correlation adaptable in any region. The thoory of dimonsional similaritude has beon applied in by far the groateot number of oorrelations and seems to possese the greatest advantages of any proposed mothod. Correlations on the basis of dimensionless groups are mare logloal, and more flexible in applioation. The advantage of this prinoiple 1108 in the oomplote universality which plaoes the experimental data of various investigatora on a ocmmon basis. Experimental varlables of the Individual apparatus are thus eliminated. A correlation of heat transfer data may be ultimately obtained by this mothod. It must be borne in wind, however, that although the relation of the variablea has been absolutely defined by this analogy, that these relations epply only if the original assumptions of the variables entering into the phenomona were ralld. Thls Iindtation has long been rooogalied and the falluse of exporimenters to obtain o complete correlation is not luo to the mothod omployed. It Indioates a fallure to oonsider all the variables affecting the problem in the origlanal asaumptions. Methods of analysis of experimental data have indicated the necessity of the introduotion of the tube length for flow in risoous and oritioal rogions. It 18 unfortunate that in this reapeot the offect of the tube length upon the heat transfor ooefflolent in short tubes intght be attributed 
to end turbulenoe ffeots making the actual relation of tube length to the coefficient. On another basis this offect might not be observed. This is espeolally true in the region of v1soous flow. The Prandtl group $(0 / / / k)$ appears in the Nusselt type equation usually to some odd power. This group, which rolates only the physioal properties of the 11quid, has been introduoed to extend the range of almpler correlation by ming it applioable to var10us 11quida. Other functional groups have been added to this type of corrolation to evaluate the of feots of oonveotion ourrents such as the ratio of $\mu / \mu$ i and $\mu / \mu_{w}$ and the Grashor group. In corrolation using the Nuseolt type equation somo few investigators, Sherwood and Petrie ${ }^{(29)}$, sleder and Tato ${ }^{(31)}$. Invest1gated kerosene among other 11quids. Generally it has been found that the value of the kerosene coefflolonts have Inoreased at a greater rate than the ooeffiolents of other 11quids. It has generally beon considered that the slope of the 21ne representing kerosene data was deflnitely greater than 0.8 in the region of from 1 to 20 times the orftical velooity. This seemed to indicate that the mothod of oorrelation was not adequate for all oonditions. Sleder and rate obtained oorrelation of berosene data of the sam order of magnitude as other IIquids by their assumption of the faotors affeoting the heat tranafer oofflolent through a 11quid fila was more noarly correct. 
The equation of s1eder and Tate, with the exooption of the group $U / C$ whloh is ovaluated at com fraotional power, 1s the Iusselt type employed by most inrentigators. Wh12e this equation 1s the mont ocmon type In turbulent flow, 1t: use in the vicoous reglon soow to be an important oontr1bution.

The ratio of the risoodty at the maln temperature to the Iscosity at the tube wall temperatures soom to be an arbitrary seleotion whloh 28 sinllar to ratios used by celburn and othere in their mothods of oorrelation. These investigatore omploged, howerer, atio in whloh the risoosity was taken at the $11 \mathrm{ln}$ tomperature rather than the wall temperature. This dimonatonless group 10 a correotion factor omployed as athod of compensating for the effeote of the rmal flom. The use of Neoosity at the wall temperature is based on the assumption of heat ILe through the 21quid ILIm and core. The use of an ererage 11 In temperature ascump heat flon through portion of the $112 \mathrm{n}$ and the 11quid oore. The effect 18 somownt more quantitative than prorlous partial assumptions. Unfortimately. as 810 der and Tate have polnted out, this method of oorrelation is IInlted to large temporature gradionts and concequantly large ratio of $U / \mu_{w}$. For anall temperature gradients where the risoosity of the Ilquid has undergone relatively small hange aoross the 
tube seotion, th1s mothod of analyale is inadequate. It roquires the possible addition of the Grashof number appearing as wome power. This agrees with the mothod of colburn (4) in which an analogy botwoen fluld frlotion and hout tranafor load to the proposal of a heat friotion group simliar to the dimonclonless friotion factor group. Inle heat tranefer torn contalning the ratio of $\mu / \mu_{\text {w }}$ and e fumotional power of the Crachor number 18 plotted against the Reynolds group. Colburn plotted friction factor rersus Reynolds numbers also and showed the inilarity existing between the two flelds.

These investigators huve resulted in correlations for beth heating and oooling data of film oopflolents. Fory fow data are arallablo for oooling: most of the work appoaring in 11terature 18 hoating data. However, the correlations with oertain corrootlons for heating and oooling show almilarity. of the correlations for oooling to dato the Dittus and Boelter and Its modifioations by 8loder and rate seom to represent the best.

A rigorous atudy of the variables eneountered in this 1101d was undertaken. Sinoe it was folt than an ompirioal form did not furnion any oontribution toward a genornl solution of anoh a complex phenomma, this study wo based on the use of the prinolplo of dinonsienal simtlaritude. Originally, a correletion of temperature rersus varlous funotional groups was quite 
thoroughly invost Igated uning data from our laboratory.

The physioal properties were determined experimantalIy except " $k$ " whloh was aseumod oonstant. The ralue was oon" sistnot with that of other investigators. Corralations on the bes1s of these 11 quid properties and the mass rate of flow as functions of the temperature and In man temporature drop were employed. The Reynolds, Iuseolt, Prandt, and Create group: were employed in thls work. Other groups containing the ooeffielent of thermal expansion were not uead as this ralue wa not known for the materlal investigated. The investigation in this direotion was abandoned finelly, as no correlation oould be obtained. Othor motheds of grouping wore attempted howover.

A plot of the Reynolds number rersus the ordinate ouggerted by Dittus and Boelter was found to glve falr dogros of oorrelation of the date through the oxitical region. The date oould be ropresented by a stralght 1 ine broaking off toward the horisontal at the lower oritioal.

Correlatione Involving bulk data are desirable sinoe no arbitrary asumptions are necessary. Data of this nature ere readily attalnablo. S1noe the Reynolde number-frietion raotor relationship is ovaluated at buik oonditions, it soom possible that corrolations of other groups oould be made in the 
ane maner. Other experimenters heve ind1oated the desirabllIty of using bulk-11quid temperatures.

Analogles have been oontinually adranoed botween

fluid friotion and the hoat trannfor ooeffiolent. This type of eorrelation employes buik temperature eraluation of the variables. Therofore, funotional relations of this nature wero Invert 1 gated.

It hav been rooogaleed by Koov11 and KoAdams (16) and others that the houting and cooling of a fluid affect the rriotion factor. The friotion factor 18, hmover, funotion of varlous varlables of whioh the preseure drop and reloolty are the controlling factors. It 1s to be expeoted from the analogy of a clotitioun riln at the tube wall, that thermal flow would alter the oharaoteriatios of this $111 \mathrm{~m}$. The presenre drop w111 be a mosure of not only the velooity flom but also the thermal flow. On this baslo the ooefsiolent of heat transfor whioh is dependent upon the flow conditions becowe a nanoticn of the pressure drop.

The hest transfor coeffielent, $h$, is dependent upon the factors affeoting the pressure drop and the thermal conduetidity of the rluid, $k$.

$$
h=\phi(k,-d P, D, D L, \nabla, \rho)
$$


In absolute undts this relationship appears ass

$$
\frac{u}{\theta^{3} t}=\left(\frac{u}{\theta^{3} t}\right)^{a}\left(\frac{u}{L \theta^{2}}\right)^{b}(L)^{a}(L)^{d}\left(\frac{u}{L^{3}}\right)^{r}
$$

Solving the fundarantal equations olmultanoously gives the relationehip of the rarlebles.

$$
h=(k / \mathfrak{D})^{2}\left(-d P / N^{2}\right)^{b}(d L / D)^{d}
$$

This funotionil expreselon oan be arranged to obtaln the prescure drops

$$
-d p / N^{2} \rho=\phi h D / k,(d L / D)
$$

Applying the pl theorem to the andyris, where there are seven varlables, and four fundumetal units, thoro are, therefore, three diwensionless groups. While this is the final rosult obtalmable by dimonsional analyste alone, it 18 physioally obrious that fluld Irietion will be proportional to the length of the pipe.

or $\quad-\mathrm{dPe} / \mathrm{N}^{2}=\mathrm{d} / \mathrm{D} \phi(\mathrm{hD} / \mathrm{k})$

Rearranglng and oonrerting preseure drop to onglneering units by divialng by $8:$

$$
-\mathrm{dPgD} / \mathrm{N}^{2} \mathrm{dL}=\varnothing \mathrm{hD} / \mathrm{L}
$$

This 2eft member is the fandliar form of the Fenning equation and therefore my bo replaced by $2 f$.

$$
\text { 2r }=-\mathrm{dPgD} / \mathrm{N}^{2} \mathrm{dL}=\phi \mathrm{hD} / \mathrm{L}
$$

Whioh relates friotion faotor and heat transfor coefflolont as:

$$
s=\delta \mathrm{nD} / \mathrm{k}
$$


The equation of Dittus and Boelter for cooling w121 be plotted at well as study of $\mathrm{hb} / \mathrm{k}$. $\mathrm{f}$. for thls and othor data. The equation of S1eder and rate w111 also bo disoussed In correlation of the data. 



\section{APPARATUS}


APPARATUS

The apparatue, F1ge, 1 and 2 , consists or a horisontal counter-ourrent 21quid-11quid hoat exohanger (A) and auxi1lary equipmont. The heat exohanger, pumpe, and storage tanks are oomplotely Inoulated for low tomperature operation.

The auxl1Lary equipwont oonel sts of a rofrigerating malt (B), refrigerant storage (C), test $11 q$ qud atorage (D). and olroulating puing (E). The hoat exohanger oonsint of a double-tube toot seotion (1), wixing ohamber: (2), oalming cootions (8), and plesometer ringe (4). Liquid and pipe thermooouples are destgated as $\mathrm{TC} 1-16$.

The Innor tube is a standard one inch brass pipe.


oant Iron sholl forine a toct seotion of exnotly 6 foot. The romining lengths of plpe on elther ond are onlining seotions. These provent ond turbulenoe from affeeting the plpe tompereture masurements. The entranoe calming sootion oontains a copper calnting oross.

The shell is aseombled in olght seotions. Three oplit-sleeres (5) are providod for thermeoouple installation. Thernooouple leads are remored from the 1 qquid apaos through 
FIa. 1

HRAT BXCEANGIR 


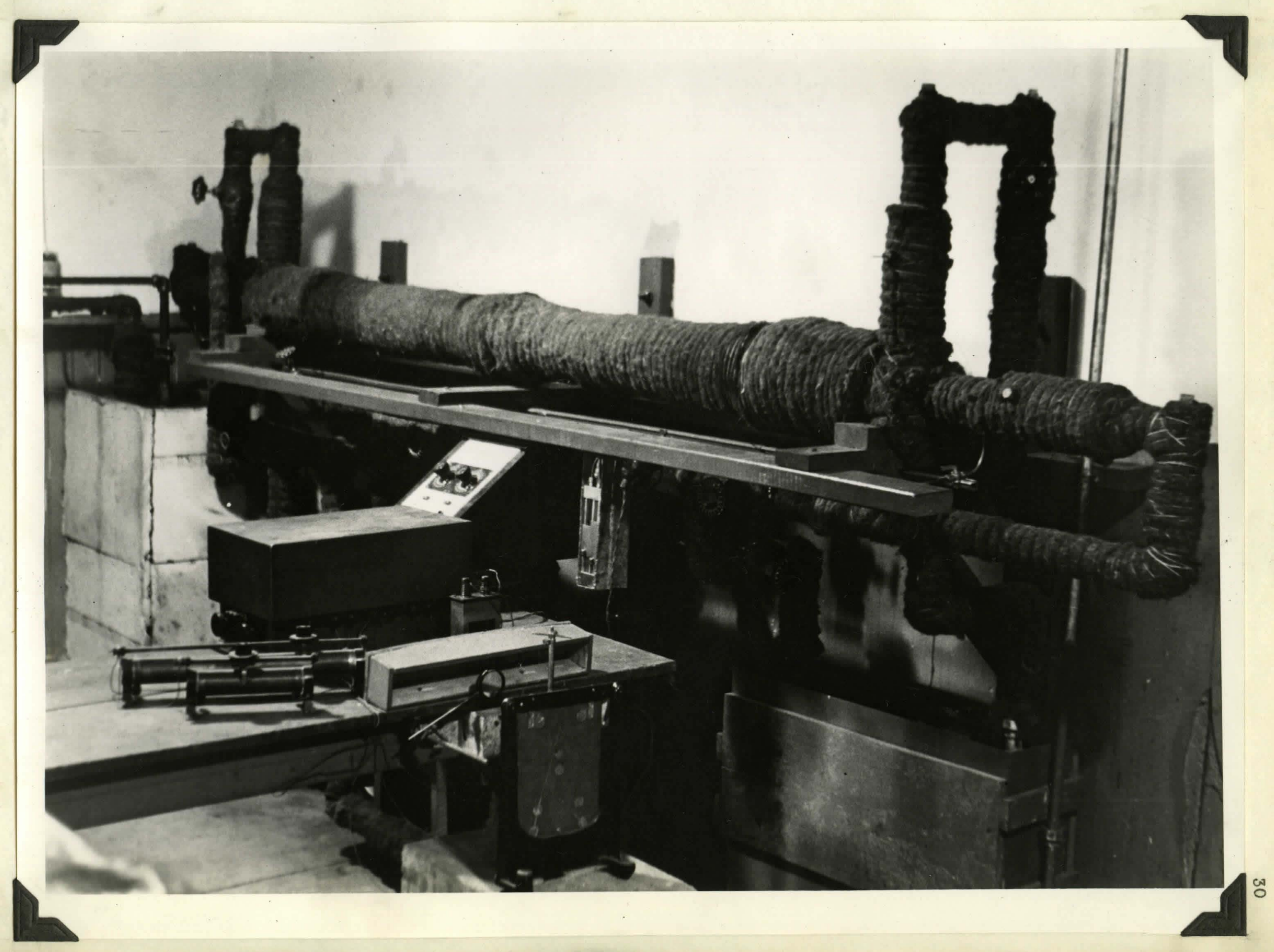


bolte in these eleeres.

Ifins ohambers are provided in the iniet and outlet Lines of the teat seotion. The nixing chambers are prooeded or followed by ealning seotions. Thermooouples wore installed at the outlet end of these ohmbers. All 11quid temporatures are arerage or bulk temperatures determined in this manor. 81xteen \#24 Bes opper-oonetantan thermoouples wore uned for temporature moavremonts. Lquid temperatures were masured by the thermoeouples in the mixing ohambers. Twelve therwocouples were used to determine the average plpe temperatwre at three polsts. Intranoe, niddle, and exit macuremonts were obtalned by four thermooouples spaed $90^{\circ}$ around the elremerenoe of the plpe. Plpe thormooouples were Inotalled by the wothed of Bobbard and Badger (12). The thermooouples wore orlglnally ohooked for uniformity of monsuremont.

The leads were conneoted to two 16 polnt seleotive owitohes. A Ingle oold junotion in serles with the seloetive onitohos was malntainod in a froosing ulxture in a vaoutm 12ack. I Leede and Northrup type I potentlomoter was ueed for roading $a 12$ thormocouples. The soouraoy of the Instrument was 0.01 mLl1rolts, correuponding to $0.08^{\circ} \mathrm{F}$ 
Thermomoter wells allowed a continual oheok on the the rmpoouples. These thermomoters also provlded a means of visual operation.

The 11quide were olroulated through the hoat exchanger by small gear pumps. Llquid rates of flow ware oomtrolled by by-pase raives around the olroulating puraps. Provisions wore mode for by-pasaing the 11quid stream Into a wolghing tank. The test 11 quid 1 low was wolghed over a wasurod period ranging from 2 minutes to 15 seconds. The 11 quid was returned to the storage by gravity slow.

The temperature of the test Ilquid was measured as It left the entranoe atxing chamber. The 21 quid tranmersed the isothermal oeluing seotions before entering the test seotion. On leaving the tent sootion it slowed through a similar 1sothermal oalming sootion. The exit temperature of 11quid was obtalned after paseing through a mixing chamber. The 11 quid was returned to the storage or by-paseed to the weightng tank.

The oooling kerosene was roolroulated through the annular ahamber surrounding the inner tube. The inlet and out let temperatures from thls eection were measured after paselng the mixing ohambers. 
TEST PROCEDURE 
TRST FROCEDURE

The kerosone for e00ling was refrigerated for a porlod of 5 to 6 hours prior to olroulation in the exohangor. The tost and rofrlgerant 11 quid prupe were started when the cooling berocene reached the destred temperature. Liquid temperatures and rates of flow wore controlled by means of by-pase 11 nes around the pumps and test 11 quid reservolr. A period of from 6 to 8 hours wa then required for the ont1re oystem to reach equilibriun sonditions.

Beoh run oonelsted of obtaining roadings for a definite rate of flow. From 50 to 100 rums wore obtalnod after the oystem had been brought to a otoady stato. Pressure drops, wase rates of flow, 11quid and plpe temporatures wero reoorded for oan sot of conditions.

The quantity of heat transforred was doternined from the tect $11 q u i d$ date. The rate of 910 of the 00011 ing lesrosene was oondtant throughout the experimont. 
PHSTCAL PROPERTIES 
bolte in these eleeres.

Ifins ohambers are provided in the iniet and outlet Lines of the teat seotion. The nixing chambers are prooeded or followed by ealning seotions. Thermooouples wore installed at the outlet end of these ohmbers. All 11quid temporatures are arerage or bulk temperatures determined in this manor. 81xteen \#24 Bes opper-oonetantan thermoouples wore uned for temporature moavremonts. Lquid temperatures were masured by the thermoeouples in the mixing ohambers. Twelve therwocouples were used to determine the average plpe temperatwre at three polsts. Intranoe, niddle, and exit macuremonts were obtalned by four thermooouples spaed $90^{\circ}$ around the elremerenoe of the plpe. Plpe thormooouples were Inotalled by the wothed of Bobbard and Badger (12). The thermooouples wore orlglnally ohooked for uniformity of monsuremont.

The leads were conneoted to two 16 polnt seleotive owitohes. A Ingle oold junotion in serles with the seloetive onitohos was malntainod in a froosing ulxture in a vaoutm 12ack. I Leede and Northrup type I potentlomoter was ueed for roading $a 12$ thormocouples. The soouraoy of the Instrument was 0.01 mLl1rolts, correuponding to $0.08^{\circ} \mathrm{F}$ 
Thermomoter wells allowed a continual oheok on the the rmpoouples. These thermomoters also provlded a means of visual operation.

The 11quide were olroulated through the hoat exchanger by small gear pumps. Llquid rates of flow ware oomtrolled by by-pase raives around the olroulating puraps. Provisions wore mode for by-pasaing the 11quid stream Into a wolghing tank. The test 11 quid 1 low was wolghed over a wasurod period ranging from 2 minutes to 15 seconds. The 11 quid was returned to the storage by gravity slow.

The temperature of the test Ilquid was measured as It left the entranoe atxing chamber. The 21 quid tranmersed the isothermal oeluing seotions before entering the test seotion. On leaving the tent sootion it slowed through a similar 1sothermal oalming sootion. The exit temperature of 11quid was obtalned after paseing through a mixing chamber. The 11 quid was returned to the storage or by-paseed to the weightng tank.

The oooling kerosene was roolroulated through the annular ahamber surrounding the inner tube. The inlet and out let temperatures from thls eection were measured after paselng the mixing ohambers. 
TEST PROCEDURE 
TRST FROCEDURE

The kerosone for e00ling was refrigerated for a porlod of 5 to 6 hours prior to olroulation in the exohangor. The tost and rofrlgerant 11 quid prupe were started when the cooling berocene reached the destred temperature. Liquid temperatures and rates of flow wore controlled by means of by-pase 11 nes around the pumps and test 11 quid reservolr. A period of from 6 to 8 hours wa then required for the ont1re oystem to reach equilibriun sonditions.

Beoh run oonelsted of obtaining roadings for a definite rate of flow. From 50 to 100 rums wore obtalnod after the oystem had been brought to a otoady stato. Pressure drops, wase rates of flow, 11quid and plpe temporatures wero reoorded for oan sot of conditions.

The quantity of heat transforred was doternined from the tect $11 q u i d$ date. The rate of 910 of the 00011 ing lesrosene was oondtant throughout the experimont. 
PHSTCAL PROPERTIES 


\section{PEISICAL PROPERTIES}

The physloal propert1es of Booene were determined experimentally with the exception of the themal conduotirity. The thermal conduotidity was taken as $0.0875(27)$. The diet112ation range, Table I, was imlar to that of other exper1monters ualng this value for lrorosene.

\section{TABLE I}

BWGLER DISTILLATION RANGE OF EOCBME

D1ot1lled over
$\%$
0
10
20
30
40
80
60
70
80
90

$$
\begin{array}{r}
\text { Eocene } \\
\text { OF. } \\
325 . \\
356 . \\
370 . \\
387 . \\
402 . \\
417 . \\
482 \\
449 . \\
471 . \\
492 .
\end{array}
$$

The visoosity was determined using a Hoeppler Viseosimotor. The variation of the visoosity over the range of 6 to $70^{\circ} \mathrm{F} .18$ shown in $\mathrm{Fig} .3$. 
$4 \pm 0$

100

360

$\frac{5}{2}$

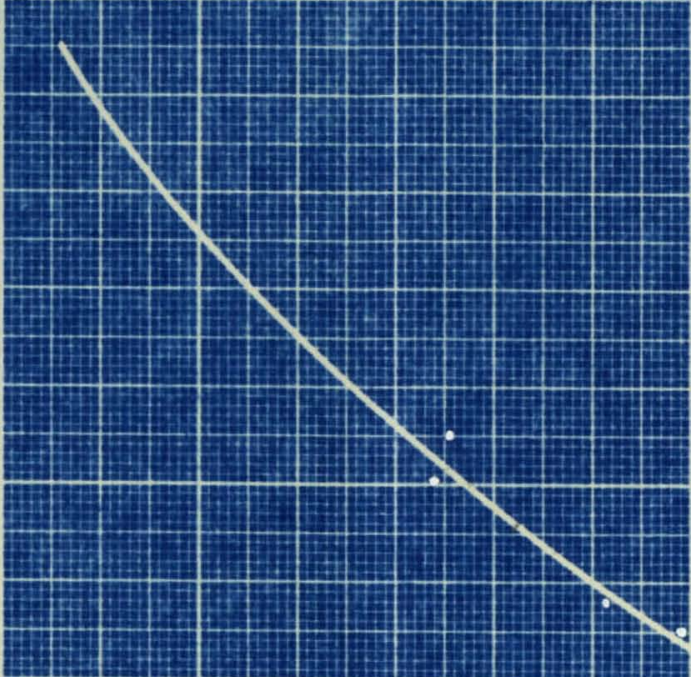

280

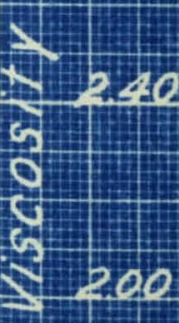

160

120 0

$20+2 .+10$

40

50

60

tomperature - Degrees Fahrenheit 

Speo1f lo heats were doternined by moseuring the temperature rise of a known welght of 11qu1d, brought about by the Introduotion of a manred quantity of eleotrieity. Spoc1f10 hoats, P1g. 4, wero determined in a Dowar Flask equipped with heating elemont and otirror. A watt-hour moter reoorded the enersy input. The temperature rise in the 11quid was moured by means of thermocouple. Calorimeter correotions wore obtalned by determining the speolflo hoats of water under inliar oonditions. These correctlons wore applied to obtuin the actual speolf10 hoats of the korosene. Extrapolation of the corrootions to be used were nooessary for values below $32^{\circ}$.

The speolfle grevity was obtalned over a range of from $-20^{\circ}$ to $80^{\circ} \mathrm{F}$. by Westphal balanoe. The ourre obtalned, F18. 5, was cheoked at several points by pyonomoter determinat10ne. 


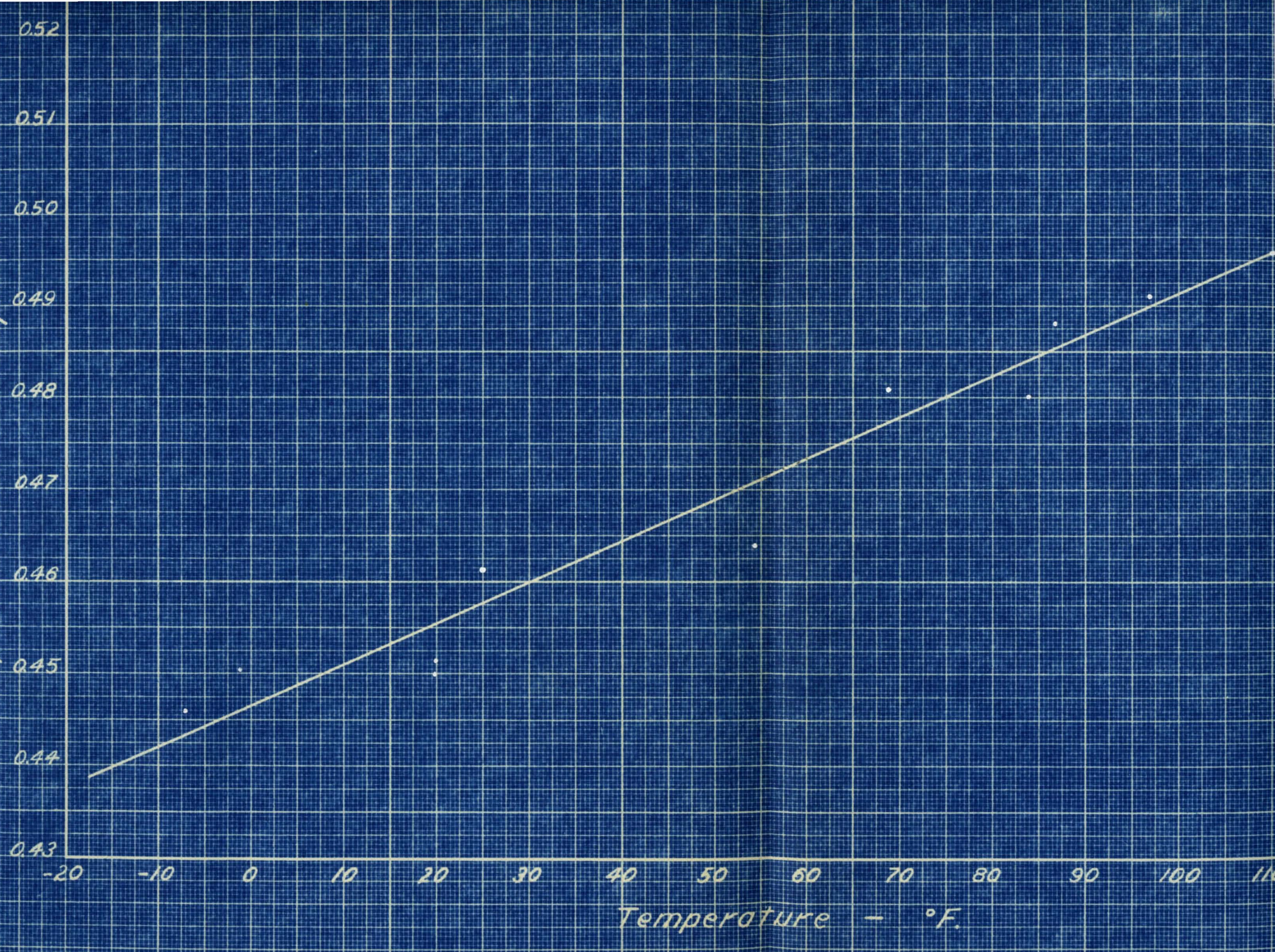






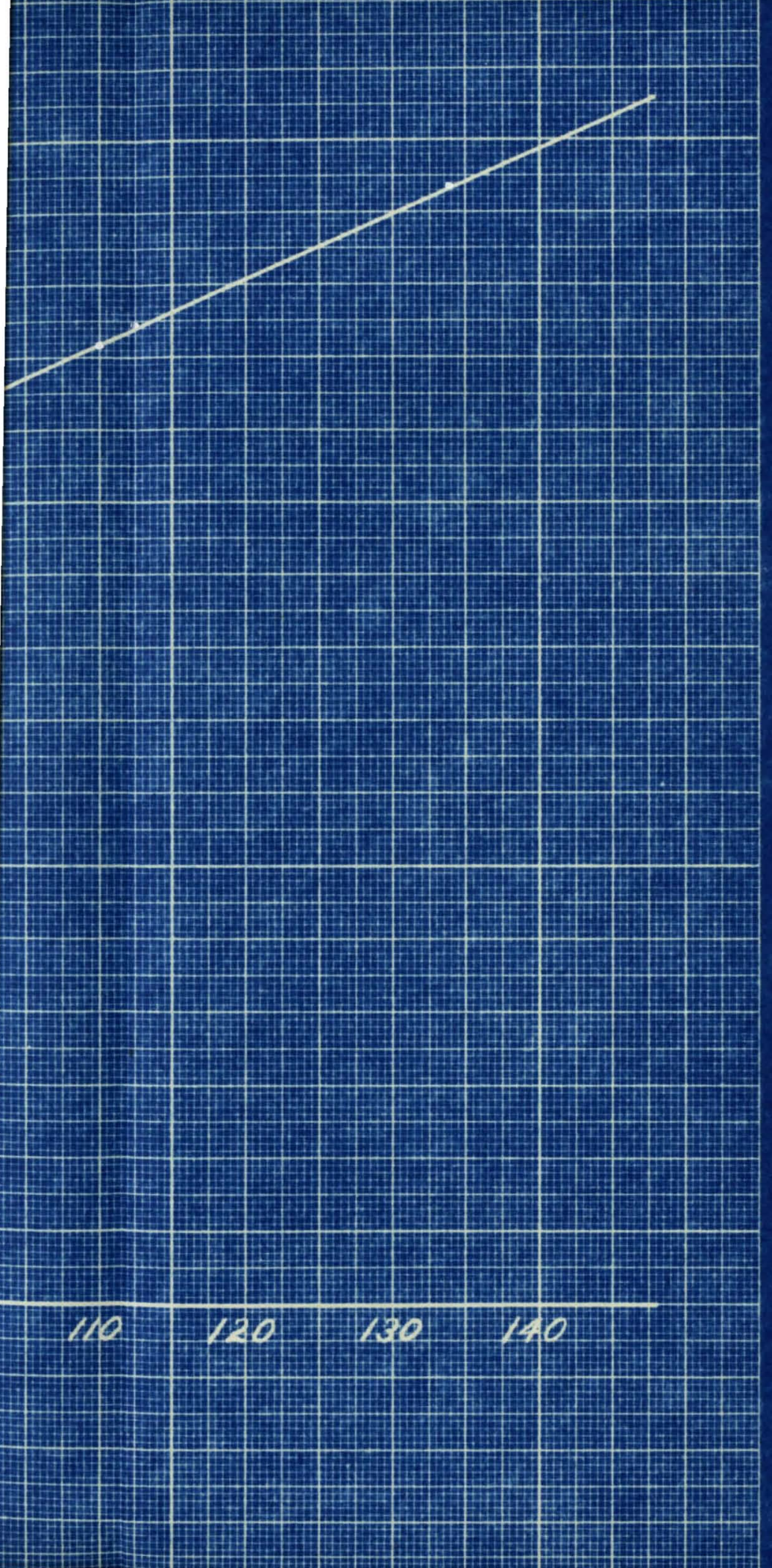


2. 825

0.815

$\frac{1}{1}$

0.805

in

2

0.79 .5

0.785

$-20-20=-12=0$

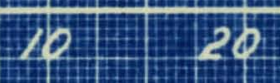

30

20

Temperature - Degree

Fig. 5 Effect of tempenature on speci 





DATA 
DARA

The experimental data is tabulated in Table II. The data has been tabulated in the order of inoreasing Reynolds numbers. That date marked 1 is from the work of Barnes (2) and Soott, and thet data marked +1 from the work of Groth (11) and Barnos.

The inlet liquid temperature $t_{1}$ and outlet temperature $t_{2}$ are bulk temperatures obtained aftor the 11quid has passed through mixing ahambers. $I_{1}$ and $T_{2}$ are average plpe temperatures at the 11quid inlet and outlet. The arerage liquid temperature is the arithmatio everage of $t_{2}$ and $t_{2}$. The mase rate of flow is gren as 1bs. per hour obtained by weighing the ilquid Plow.

The in moan i I we ealoulated from the tomperature differonoes at inlet and outlet 11 quid oonditions. The heat transfer coefflolent was caloulated on the basis of the in moan $I$. The therwal conduotirity $k$, appearing in the Iuseelt and Prandt 1 groups has beon oraluated at oonstant $\mathrm{val}$ as of 0.0875 . The phyaion properties of the IIquid entering the Reynolds and Prandt groups are taken at bulk oonditions. The friotion feotor, $f$, was obtalned from an onlarged plot of the laothermal fiction faoton re. Reynolds number. The run numbers correspond to conseoutite numberIng of the experimontal data in order of Inorvasing Roynolds numbers and not in ohronologloal ordor. 


\begin{tabular}{|c|c|c|c|c|c|c|c|c|c|c|c|c|c|}
\hline $\begin{array}{l}\text { Run } \\
\text { No. }\end{array}$ & $\begin{array}{l}\text { Test } \\
\text { Liquid } \\
\text { Injot }\end{array}$ & $\begin{array}{l}\text { Test } \\
\text { Liquid } \\
\text { Outiot }\end{array}$ & $\begin{array}{l}\text { Inlet } \\
\text { Pipe } \\
\text { Tomp. }\end{array}$ & $\begin{array}{l}\text { Outlot } \\
\text { Pipo } \\
\text { Tomp. }\end{array}$ & 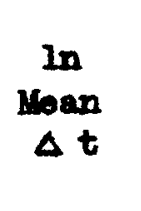 & $\begin{array}{c}\text { Ar. } \\
\text { Liquid } \\
\text { Temp. }\end{array}$ & $\# / h r$ & $\frac{D G}{\mu}$ & $f$ & $\mathbf{h}$ & $\frac{h D}{k}$ & $\frac{{ }^{c} \mathrm{p} \mu}{\mathrm{k}}$ & $\frac{\frac{h D}{k}}{\left(\frac{p}{k}\right)^{3}}$ \\
\hline $\begin{array}{l}1 \\
2 \\
3 \\
4 \\
5\end{array}$ & $\begin{array}{l}49.108 \\
47.004 \\
11.724 \\
41.00 \\
4.700\end{array}$ & $\begin{array}{l}27.4 n \\
80.040 \\
31.690 \\
29.469 \\
82.222\end{array}$ & $\begin{array}{l}22.700 \\
23.200 \\
22.454 \\
21.065 \\
23.052\end{array}$ & $\begin{array}{l}10.502 \\
21.005 \\
21.690 \\
29.804 \\
21.07\end{array}$ & $\begin{array}{l}16.66 \\
16.42 \\
14.28 \\
14.62 \\
14.67\end{array}$ & $\begin{array}{l}87.827 \\
38.016 \\
36.701 \\
36.063 \\
37.461\end{array}$ & $\begin{array}{r}69.4 \\
76.6 \\
136.6 \\
200.2 \\
116.4\end{array}$ & $\begin{array}{l}179 . \\
206 . \\
246 . \\
262 . \\
200 .\end{array}$ & $\begin{array}{l}.005 \\
.008 \\
.008 \\
.006 \\
.064\end{array}$ & $\begin{array}{l}26.0 \\
24.2 \\
27.2 \\
23.8 \\
24.7\end{array}$ & $\begin{array}{l}25.9 \\
24.1 \\
27.1 \\
25.7 \\
24.4\end{array}$ & $\begin{array}{l}28 . .8 \\
29.6 \\
30.2 \\
30.6 \\
50.1\end{array}$ & $\begin{array}{l}9.35 \\
8.70 \\
0.72 \\
8.50 \\
8.58\end{array}$ \\
\hline $\begin{array}{r}6 \\
7 \\
8 \\
9 \\
10\end{array}$ & $\begin{array}{l}42.478 \\
41.846 \\
40.347 \\
60.624 \\
30.072\end{array}$ & $\begin{array}{l}34.232 \\
34.300 \\
32.077 \\
35.421 \\
32.488\end{array}$ & $\begin{array}{l}21.305 \\
26.008 \\
25.080 \\
21.065 \\
21.122\end{array}$ & $\begin{array}{l}23.075 \\
26.027 \\
24.007 \\
21.221 \\
21.600\end{array}$ & $\begin{array}{l}14.51 \\
11.01 \\
12.31 \\
16.40 \\
14.05\end{array}$ & $\begin{array}{l}30.205 \\
37.028 \\
36.668 \\
37.018 \\
85.730\end{array}$ & $\begin{array}{l}289.0 \\
247.0 \\
162.0 \\
184.0 \\
210.0\end{array}$ & $\begin{array}{l}361 . \\
380 . \\
421 . \\
470 . \\
628 .\end{array}$ & $\begin{array}{l}.048 \\
.048 \\
.009 \\
.058 \\
.082\end{array}$ & $\begin{array}{l}25.3 \\
25.8 \\
27.2 \\
24.2 \\
27.8\end{array}$ & $\begin{array}{l}23.2 \\
25.7 \\
27.2 \\
24.1 \\
27.7\end{array}$ & $\begin{array}{l}29.7 \\
29.6 \\
80.6 \\
30.2 \\
30.6\end{array}$ & $\begin{array}{l}8.42 \\
8.02 \\
8.78 \\
8.67 \\
9.91\end{array}$ \\
\hline $\begin{array}{l}11 \\
12 \\
13+ \\
14 \\
15\end{array}$ & $\begin{array}{l}88.060 \\
37.984 \\
89.72 \\
28.718 \\
26.050\end{array}$ & $\begin{array}{l}32.658 \\
35.021 \\
53.24 \\
22.632 \\
22.765\end{array}$ & $\begin{array}{l}21.122 \\
20.465 \\
65.7 \\
11.031 \\
0.400\end{array}$ & $\begin{array}{c}20.645 \\
20.700 \\
36.2 \\
20.500 \\
9.480\end{array}$ & $\begin{array}{l}14.42 \\
15.26 \\
16.67 \\
18.06 \\
14.86\end{array}$ & $\begin{array}{l}36.286 \\
35.000 \\
86.48 \\
23.676 \\
24.400\end{array}$ & $\begin{array}{l}262.0 \\
265.0 \\
225.0 \\
418.0 \\
423.0\end{array}$ & $\begin{array}{l}665 . \\
680 . \\
728 . \\
800 . \\
008 .\end{array}$ & $\begin{array}{l}.026 \\
.026 \\
.0210 \\
.0177 \\
.0176\end{array}$ & $\begin{array}{l}27.8 \\
24.2 \\
25.2 \\
27.2 \\
26.2\end{array}$ & $\begin{array}{l}27.0 \\
24.1 \\
28.0 \\
27.0 \\
25.2\end{array}$ & $\begin{array}{l}30.7 \\
30.7 \\
24.2 \\
38.0 \\
34.7\end{array}$ & $\begin{array}{l}8.98 \\
8.64 \\
0.6 \\
0.8 \\
8.7\end{array}$ \\
\hline $\begin{array}{l}16 \\
17 \\
18 \\
19 \\
20\end{array}$ & $\begin{array}{l}26.317 \\
23.476 \\
22.054 \\
23.296 \\
36.529\end{array}$ & $\begin{array}{l}22.087 \\
20.466 \\
19.702 \\
20.066 \\
38.421\end{array}$ & $\begin{array}{r}30.500 \\
7.680 \\
8.355 \\
9.000 \\
20.678\end{array}$ & $\begin{array}{r}9.970 \\
6.602 \\
0.207 \\
8.012 \\
20.201\end{array}$ & $\begin{array}{l}14.42 \\
14.78 \\
12.47 \\
12.09 \\
14.98\end{array}$ & $\begin{array}{l}24.658 \\
21.836 \\
20.078 \\
22.077 \\
34.875\end{array}$ & $\begin{array}{l}413.0 \\
488.0 \\
608.0 \\
510.0 \\
458.0\end{array}$ & $\begin{array}{l}606 . \\
968 . \\
1041 . \\
1078 . \\
1086 .\end{array}$ & $\begin{array}{l}.0176 \\
.0265 \\
.0268 \\
.0158 \\
.016\end{array}$ & $\begin{array}{l}26.6 \\
26.0 \\
26.5 \\
27.5 \\
26.2\end{array}$ & $\begin{array}{l}26.4 \\
26.0 \\
26.5 \\
27.5 \\
26.1\end{array}$ & $\begin{array}{l}36.7 \\
86.2 \\
36.7 \\
36.0 \\
80.7\end{array}$ & $\begin{array}{l}9.1 \\
8.9 \\
9.0 \\
9.4 \\
8.90\end{array}$ \\
\hline $\begin{array}{l}21 \\
22 \\
23 \\
24 \\
25^{+}\end{array}$ & $\begin{array}{l}21.032 \\
22.720 \\
22.276 \\
21.300 \\
68.75\end{array}$ & $\begin{array}{l}20.624 \\
20.245 \\
20.700 \\
18.946 \\
50.72\end{array}$ & $\begin{array}{l}8.115 \\
8.280 \\
7.986 \\
7.447 \\
16.0\end{array}$ & $\begin{array}{c}8.601 \\
7.680 \\
7.725 \\
7.280 \\
42.0\end{array}$ & $\begin{array}{l}12.32 \\
13.50 \\
13.11 \\
12.65 \\
17.07\end{array}$ & $\begin{array}{l}20.678 \\
21.045 \\
21.058 \\
20.128 \\
61.74\end{array}$ & $\begin{array}{l}653 . \\
635 . \\
610.0 \\
665.0 \\
342.0\end{array}$ & $\begin{array}{l}2100 . \\
1218, \\
1220 . \\
1120 . \\
1120 .\end{array}$ & $\begin{array}{l}.0285 \\
.0165 \\
.0161 \\
.0255 \\
.0151\end{array}$ & $\begin{array}{l}27.6 \\
26.4 \\
28.4 \\
26.9 \\
28.2\end{array}$ & $\begin{array}{l}27.6 \\
28.4 \\
28.4 \\
20.0 \\
28.1\end{array}$ & $\begin{array}{l}36.8 \\
36.8 \\
36.6 \\
37.6 \\
22.0\end{array}$ & $\begin{array}{l}9.4 \\
9.7 \\
9.7 \\
9.8 \\
9.2\end{array}$ \\
\hline
\end{tabular}

- Dete or Barnes and seott 


\begin{tabular}{|c|c|c|c|c|c|c|c|c|c|c|c|c|c|}
\hline $\begin{array}{l}\text { Run } \\
\text { No. }\end{array}$ & $\begin{array}{l}\text { Test } \\
\text { Liquid } \\
\text { Inlet }\end{array}$ & $\begin{array}{l}\text { Test } \\
\text { Liquid } \\
\text { Outiot }\end{array}$ & $\begin{array}{l}\text { Inlet } \\
\text { Pipe } \\
\text { Tomp. }\end{array}$ & $\begin{array}{c}\text { Outlet } \\
\text { Pipe } \\
\text { Temp. }\end{array}$ & $\begin{array}{l}\ln _{\operatorname{Moan}} \\
\Delta t\end{array}$ & $\begin{array}{c}\text { Ar. } \\
\text { Liquid } \\
\text { Temp. }\end{array}$ & $\# / h r$ & $\frac{D G}{\mu}$ & $f$ & $\mathbf{h}$ & $\frac{h D}{x}$ & $\frac{{ }^{c} \mathrm{p} \mu}{k}$ & $\frac{\frac{h D}{k}}{\left(\frac{p}{p} / y\right.}$ \\
\hline $\begin{array}{l}26 \\
27^{+} \\
28^{*} \\
29 \\
30^{*}\end{array}$ & $\begin{array}{l}2.061 \\
65.04 \\
63.09 \\
22.843 \\
48.781\end{array}$ & $\begin{array}{l}20.609 \\
62.11 \\
60.00 \\
20.234 \\
40.654\end{array}$ & $\begin{array}{c}9.001 \\
. .97 \\
46.6 \\
0.721 \\
53.315\end{array}$ & $\mid \begin{array}{c}8.667 \\
4.48 \\
39.7 \\
8.922 \\
27.984\end{array}$ & $\begin{array}{l}13.00 \\
16.78 \\
16.25 \\
12.12 \\
11.00\end{array}$ & $\begin{array}{l}21.72 \\
63.08 \\
61.05 \\
21.388 \\
41.698\end{array}$ & $\begin{array}{l}570.0 \\
349.0 \\
386.0 \\
623.0 \\
488.0\end{array}$ & $\begin{array}{l}2188 . \\
1243 . \\
2300 . \\
1502 . \\
1329 .\end{array}$ & $\begin{array}{l}.0160 \\
.0160 \\
.0147 \\
.0147 \\
.0146\end{array}$ & $\begin{array}{l}27.6 \\
22.0 \\
26.6 \\
52.7 \\
26.0\end{array}$ & $\begin{array}{l}27.6 \\
22.2 \\
25.5 \\
32.7 \\
25.9\end{array}$ & $\begin{array}{l}3 e .2 \\
22.2 \\
25.0 \\
36.3 \\
28.4\end{array}$ & $\begin{array}{r}9.4 \\
8.7 \\
9.9 \\
11.8 \\
9.5\end{array}$ \\
\hline $\begin{array}{l}31^{+} \\
32^{+} \\
33^{*} \\
34 \\
35\end{array}$ & $\begin{array}{l}68.09 \\
68.65 \\
43.85 \\
21.200 \\
28.664\end{array}$ & $\begin{array}{l}60.00 \\
62.76 \\
10.827 \\
19.612 \\
2 . .248\end{array}$ & $\begin{array}{l}46.5 \\
46.75 \\
51.342 \\
8.167 \\
13.674\end{array}$ & $\mid \begin{array}{l}39.7 \\
42.36 \\
24.869 \\
7.447 \\
13.706\end{array}$ & $\begin{array}{r}18.28 \\
21.20 \\
13.06 \\
12.08 \\
8.91\end{array}$ & $\begin{array}{l}61.06 \\
64.68 \\
42.091 \\
20.456 \\
22.064\end{array}$ & $\begin{array}{l}398.0 \\
394.0 \\
518.0 \\
690.0 \\
683.0\end{array}$ & $\begin{array}{l}1370 . \\
1410^{\circ} \\
1410^{\circ} \\
1419 . \\
1460 .\end{array}$ & $\begin{array}{l}.0245 \\
.0244 \\
.0145 \\
.0248 \\
.0141\end{array}$ & $\begin{array}{l}26.6 \\
20.4 \\
26.4 \\
26.2 \\
30.3\end{array}$ & $\begin{array}{l}26.5 \\
20.3 \\
26.3 \\
26.2 \\
30.5\end{array}$ & $\begin{array}{l}23.0 \\
28.1 \\
28.3 \\
36.9 \\
36.6\end{array}$ & $\begin{array}{r}9.9 \\
6.0 \\
0.6 \\
8.9 \\
10.4\end{array}$ \\
\hline $\begin{array}{l}36 \\
37 \\
38^{+} \\
39 \\
40^{+}\end{array}$ & $\mid \begin{array}{l}29.657 \\
60.03 \\
20.270 \\
56.21 \\
65.48\end{array}$ & $\begin{array}{l}18.236 \\
56.21 \\
18.002 \\
62.62 \\
60.44\end{array}$ & $\begin{array}{l}7.723 \\
42.5 \\
6.116 \\
39.6 \\
40.20\end{array}$ & $\begin{array}{c}7.846 \\
86.6 \\
6.498 \\
54.6 \\
4.11\end{array}$ & $\begin{array}{l}21.00 \\
18.38 \\
13.50 \\
17.27 \\
16.60\end{array}$ & $\begin{array}{l}18.947 \\
68.15 \\
19.890 \\
64.87 \\
61.84\end{array}$ & $\begin{array}{l}720.0 \\
454.0 \\
865.0 \\
651.0 \\
606.0\end{array}$ & $\begin{array}{l}1460 . \\
1602 . \\
1727 . \\
1765 . \\
1760 .\end{array}$ & $\begin{array}{l}.0142 \\
.0140 \\
.0138 \\
.0158 \\
.0158\end{array}$ & $\begin{array}{l}25.4 \\
28.1 \\
31.2 \\
32.9 \\
23.6\end{array}$ & $\begin{array}{l}25.4 \\
26.0 \\
31.2 \\
31.8 \\
28.7\end{array}$ & $\begin{array}{l}87.6 \\
23.8 \\
57.6 \\
24.6 \\
28.7\end{array}$ & $\begin{array}{r}8.5 \\
10.0 \\
10.6 \\
12.4 \\
9.5\end{array}$ \\
\hline $\begin{array}{l}41 \\
42 \\
43 \\
44 \\
45\end{array}$ & {$\left[\begin{array}{l}20.772 \\
2.319 \\
21.966 \\
20.257 \\
21.066\end{array}\right.$} & $\begin{array}{l}10.346 \\
22.498 \\
20.468 \\
27.926 \\
20.458\end{array}$ & $\begin{array}{r}9.445 \\
10.022 \\
10.855 \\
6.150 \\
10.656\end{array}$ & $\begin{array}{r}0.178 \\
9.134 \\
10.099 \\
8.659 \\
60.909\end{array}$ & $\begin{array}{l}10.59 \\
13.831 \\
10.30 \\
22.20 \\
10.31\end{array}$ & $\begin{array}{l}20.084 \\
28.409 \\
20.643 \\
20.691 \\
21.211\end{array}$ & $\begin{array}{r}870.0 \\
835.0 \\
915.0 \\
945.0 \\
925.0\end{array}$ & $\begin{array}{l}37 \% \text {. } \\
1810 . \\
1008 . \\
1890 . \\
1004 .\end{array}$ & $\begin{array}{l}.0132 \\
.0131 \\
.0129 \\
.0129 \\
.0128\end{array}$ & $\begin{array}{l}31.4 \\
30.6 \\
37.0 \\
28.2 \\
37.0\end{array}$ & $\begin{array}{l}31.4 \\
30.4 \\
86.9 \\
28.2 \\
37.0\end{array}$ & $\begin{array}{l}87.1 \\
58.0 \\
86.8 \\
37.9 \\
36.5\end{array}$ & $\begin{array}{r}10.6 \\
10.6 \\
12.6 \\
9.6 \\
12.6\end{array}$ \\
\hline $\begin{array}{l}46^{*} \\
47 \\
48 \\
49 \\
50\end{array}$ & $\begin{array}{l}2.731 \\
18.680 \\
24.875 \\
22.065 \\
20.245\end{array}$ & $\begin{array}{r}11.273 \\
67.170 \\
68.821 \\
20.767\end{array}$ & $\begin{array}{r}36.283 \\
6.496 \\
12.058 \\
12.206 \\
11.709\end{array}$ & $\begin{array}{r}52.000 \\
6.426 \\
11.042 \\
11.842 \\
21.45\end{array}$ & $\begin{array}{r}7.70 \\
20.80 \\
10.61 \\
9.13 \\
0.05\end{array}$ & $\mid \begin{array}{l}42.982 \\
27.925 \\
23.098 \\
21.367 \\
19.036\end{array}$ & $\begin{array}{r}705.0 \\
1020.0 \\
980.0 \\
990.0 \\
1060.0\end{array}$ & $\begin{array}{l}1920 . \\
2011 . \\
2066 . \\
2040 . \\
2128 .\end{array}$ & $\begin{array}{l}.0128 \\
.0127 \\
.0226 \\
.0126 \\
.0124\end{array}$ & $\begin{array}{l}39.8 \\
40.6 \\
39.4 \\
36.9 \\
86.8\end{array}$ & $\begin{array}{l}38.7 \\
40.6 \\
59.4 \\
35.9 \\
36.8\end{array}$ & $\begin{array}{l}29.4 \\
38.4 \\
85.5 \\
56.6 \\
\$ 7.4\end{array}$ & $\begin{array}{l}14.5 \\
13.6 \\
13.5 \\
12.2 \\
12.5\end{array}$ \\
\hline
\end{tabular}


TABLE II HEAT EXCHANGER DATA

\begin{tabular}{|c|c|c|c|c|c|c|c|c|c|c|c|c|c|}
\hline $\begin{array}{l}\text { Rum } \\
\text { No. }\end{array}$ & $\begin{array}{l}\text { Test } \\
\text { Liquid } \\
\text { Inlet }\end{array}$ & $\begin{array}{l}\text { Teot } \\
\text { Liguid } \\
\text { Outiot }\end{array}$ & $\begin{array}{l}\text { Inlot } \\
\text { Pipe } \\
\text { Pemp. }\end{array}$ & $\begin{array}{l}\text { Outlet } \\
\text { Pipe } \\
\text { Tomp. }\end{array}$ & $\begin{array}{l}\ln \\
\operatorname{Moan} \\
\Delta t\end{array}$ & $\begin{array}{l}\text { Av. } \\
\text { Liquid } \\
\text { Temp. }\end{array}$ & $\# / h r$ & $\frac{D G}{\mu}$ & $f$ & $\mathrm{~h}$ & $\frac{h D}{k}$ & & $\frac{\frac{h D}{k}}{\left(\frac{p / y}{k}\right)}$ \\
\hline $\begin{array}{l}52 \\
58 \\
55^{+} \\
54 \\
65\end{array}$ & $\begin{array}{l}26.424 \\
20.210 \\
55.44 \\
21.642 \\
18.99\end{array}$ & $\mid \begin{array}{l}19.226 \\
10.065 \\
63.865 \\
20.025 \\
46.082\end{array}$ & $\begin{array}{r}7.100 \\
8.400 \\
41.460 \\
10.009 \\
42.508\end{array}$ & $\begin{array}{r}7.160 \\
0.20 \\
20.148 \\
21.300 \\
30.200\end{array}$ & $\begin{array}{r}10.03 \\
10.22 \\
17.77 \\
0.85 \\
7.48\end{array}$ & $\begin{array}{l}17.826 \\
20.036 \\
58.049 \\
21.078 \\
40.080\end{array}$ & $\begin{array}{r}214.0 \\
2126.0 \\
120.0 \\
2110.0 \\
805.0\end{array}$ & $\begin{array}{l}2256 . \\
2264 . \\
2270 . \\
2300 . \\
2200 .\end{array}$ & $\begin{array}{l}.0121 \\
.0221 \\
.0121 \\
.0120 \\
.0219\end{array}$ & $\begin{array}{l}85.7 \\
35.4 \\
8.00 \\
47.0 \\
40.4\end{array}$ & $\begin{array}{l}85.7 \\
35.4 \\
85.5 \\
46.9 \\
40.8\end{array}$ & $\begin{array}{l}38.4 \\
37.6 \\
24.0 \\
36.6 \\
26.2\end{array}$ & $\begin{array}{l}12.0 \\
12.0 \\
13.7 \\
16.0 \\
15.1\end{array}$ \\
\hline $\begin{array}{l}56^{+} \\
57 \\
68 \\
60^{\circ} \\
60\end{array}$ & $\begin{array}{c}65.24 \\
22.182 \\
20.001 \\
12.528 \\
1 . .012\end{array}$ & $\begin{array}{l}52.08 \\
20.654 \\
28.670 \\
10.610 \\
24.008\end{array}$ & $\begin{array}{l}41.6 \\
11.704 \\
16.605 \\
82.788 \\
5.538\end{array}$ & $\begin{array}{l}38.8 \\
\mathbf{2 1 . 8 9 8} \\
\mathbf{1 5 . 9 7 2} \\
20.028 \\
5.908\end{array}$ & $\begin{array}{r}11.26 \\
8.62 \\
13.48 \\
10.48 \\
0.60\end{array}$ & $\begin{array}{l}8.05 \\
20.476 \\
29.706 \\
42.416 \\
16.450\end{array}$ & $\begin{array}{r}761.0 \\
1270.0 \\
1085.0 \\
925.0 \\
1320.0\end{array}$ & $\begin{array}{l}2387 . \\
2412 . \\
2418 . \\
2400 . \\
2800 .\end{array}$ & $\begin{array}{l}.0110 \\
.0128 \\
.0128 \\
.0117 \\
.0127\end{array}$ & $\begin{array}{l}45.7 \\
47.3 \\
48.7 \\
44.8 \\
40.8\end{array}$ & $\begin{array}{l}45.6 \\
47.2 \\
46.6 \\
4.1 \\
40.2\end{array}$ & $\begin{array}{l}24.8 \\
38.6 \\
32.8 \\
28.6 \\
39.6\end{array}$ & $\begin{array}{l}17.4 \\
16.1 \\
16.0 \\
16.2 \\
25.3\end{array}$ \\
\hline $\begin{array}{l}62^{\circ} \\
62 \\
68 \\
64+ \\
65\end{array}$ & $\begin{array}{l}4.216 \\
12.810 \\
25.029 \\
6.36 \\
28.840\end{array}$ & $\mid \begin{array}{l}42.188 \\
11.081 \\
25.075 \\
67.65 \\
24.807\end{array}$ & $\begin{array}{r}6.327 \\
3.240 \\
16.350 \\
51.4 \\
18.901\end{array}$ & $\begin{array}{l}38.658 \\
3.510 \\
14.775 \\
46.3 \\
10.300\end{array}$ & $\begin{array}{l}5.708 \\
0.00 \\
9.302 \\
0.68 \\
6.00\end{array}$ & $\begin{array}{l}42.002 \\
12.870 \\
24.482 \\
58.46 \\
25.274\end{array}$ & $\begin{array}{r}228.0 \\
2305.0 \\
1200.0 \\
706.0 \\
1220.0\end{array}$ & $\begin{array}{l}2510 . \\
2510 . \\
2680 . \\
2640 . \\
2720 .\end{array}$ & $\begin{array}{l}.0217 \\
.0217 \\
.0215 \\
.01215 \\
.0121\end{array}$ & $\begin{array}{l}80.3 \\
88.3 \\
10.9 \\
45.1 \\
62.0\end{array}$ & $\begin{array}{l}60.1 \\
58.3 \\
40.8 \\
43.0 \\
62.9\end{array}$ & $\begin{array}{l}28.4 \\
41.8 \\
37.4 \\
28.7 \\
34.4\end{array}$ & $\begin{array}{l}18.5 \\
12.5 \\
14.2 \\
16.7 \\
18.0\end{array}$ \\
\hline $\begin{array}{l}65^{+} \\
67 \\
68 \\
69^{+} \\
70^{\circ}\end{array}$ & $\begin{array}{l}61.28 \\
10.257 \\
27.294 \\
63.75 \\
0.030\end{array}$ & $\begin{array}{l}59.36 \\
18.088 \\
16.282 \\
60.08 \\
49.240\end{array}$ & $\begin{array}{c}52.4 \\
6.080 \\
7.08 \\
44.60 \\
16.128\end{array}$ & $\begin{array}{c}4.2 \\
8.290 \\
7.180 \\
35.44 \\
42.484\end{array}$ & $\begin{array}{r}10.78 \\
20.22 \\
9.72 \\
22.68 \\
6.84\end{array}$ & $\begin{array}{l}00.24 \\
18.68 \\
16.798 \\
61.82 \\
40.812\end{array}$ & $\begin{array}{r}709.0 \\
1365.0 \\
2425.0 \\
705.0 \\
000.0\end{array}$ & $\begin{array}{l}2720 . \\
2780 . \\
2706 . \\
2770 . \\
2800 .\end{array}$ & $\begin{array}{l}.0113 \\
.0118 \\
.0113 \\
.0125 \\
.0212\end{array}$ & $\begin{array}{l}37.4 \\
4.0 \\
42.2 \\
57.0 \\
52.0\end{array}$ & $\begin{array}{l}37.3 \\
48.8 \\
11.1 \\
86.8 \\
61.8\end{array}$ & $\begin{array}{l}25.2 \\
37.9 \\
38.0 \\
22.7 \\
26.6\end{array}$ & $\begin{array}{l}14.5 \\
14.0 \\
13.7 \\
14.6 \\
19.4\end{array}$ \\
\hline $\begin{array}{l}71 \\
72^{+} \\
78 \\
74^{*} \\
75^{+}\end{array}$ & $\begin{array}{l}25.794 \\
68.21 \\
24.09 \\
44.012 \\
66.08\end{array}$ & $\begin{array}{l}14.040 \\
60.03 \\
25.094 \\
6.230 \\
02.11\end{array}$ & $\begin{array}{l}6.160 \\
52.08 \\
16.480 \\
85.046 \\
18.2\end{array}$ & $\begin{array}{l}6.205 \\
16.2 \\
26.020 \\
20.062 \\
36.7\end{array}$ & $\begin{array}{c}8.80 \\
11.70 \\
8.102 \\
10.48 \\
22.18\end{array}$ & $\begin{array}{l}26.227 \\
61.10 \\
24.430 \\
48.246 \\
64.84\end{array}$ & $\begin{array}{r}1500.0 \\
252.0 \\
2308.0 \\
2120.0 \\
802.0\end{array}$ & $\begin{array}{l}2687 . \\
2930 . \\
5040 . \\
5000 . \\
3120 .\end{array}$ & $\begin{array}{l}.0212 \\
.0112 \\
.0110 \\
.0210 \\
.0100\end{array}$ & $\begin{array}{l}65.1 \\
42.6 \\
4.6 \\
62.6 \\
52.1\end{array}$ & $\begin{array}{l}63.0 \\
42.6 \\
45.6 \\
6.5 \\
82.0\end{array}$ & $\begin{array}{l}10.0 \\
23.0 \\
34.7 \\
28.1 \\
2.2\end{array}$ & $\begin{array}{l}17.6 \\
16.6 \\
16.1 \\
19.8 \\
20.7\end{array}$ \\
\hline
\end{tabular}




\begin{tabular}{|c|c|c|c|c|c|c|c|c|c|c|c|c|c|}
\hline $\begin{array}{l}\text { Run } \\
\text { No. }\end{array}$ & $\begin{array}{l}\text { Test } \\
\text { Liquid } \\
\text { Inlet }\end{array}$ & $\begin{array}{c}\text { Tost } \\
\text { Liquid } \\
\text { Outlot }\end{array}$ & $\begin{array}{l}\text { Inlet } \\
\text { Pipe } \\
\text { Terp. }\end{array}$ & $\begin{array}{l}\text { Outlet } \\
\text { Pipe } \\
\text { Temp. }\end{array}$ & $\begin{array}{c}\ln _{\text {Moan }} \\
\Delta t\end{array}$ & $\begin{array}{c}\text { AT. } \\
\text { Liquid } \\
\text { Temp. }\end{array}$ & $\# / \mathrm{hr}$ & $\frac{D G}{\mu}$ & $f$ & $\mathrm{~h}$ & $\frac{h D}{k}$ & $\frac{{ }^{c} p \mu}{k}$ & $\frac{\frac{h D}{k}}{\left(\frac{c_{p} / j^{-3}}{k}\right)^{3}}$ \\
\hline $\begin{array}{l}76^{+} \\
77 \\
78 \\
79 \\
80\end{array}$ & $\begin{array}{l}83.06 \\
21.076 \\
20.017 \\
40.289 \\
24.940\end{array}$ & $\begin{array}{l}64.02 \\
20.701 \\
20.455 \\
19.167 \\
20.097\end{array}$ & $\begin{array}{l}47.2 \\
12.064 \\
12.183 \\
39.615 \\
17.170\end{array}$ & $\begin{array}{l}12.0 \\
11.007 \\
21.007 \\
33.007 \\
26.004\end{array}$ & $\begin{array}{r}12.28 \\
8.36 \\
7.70 \\
11.72 \\
7.402\end{array}$ & $\begin{array}{l}05.00 \\
20.300 \\
19.002 \\
48.205 \\
24.510\end{array}$ & $\begin{array}{r}270.0 \\
1600.0 \\
2676.0 \\
2120.0 \\
1000.0\end{array}$ & $\begin{array}{l}\mathbf{3 2 0 0 .} \\
\mathbf{3 2 0 6 .} \\
\mathbf{3 2 1 8 .} \\
\mathbf{3 2 7 .} \\
\mathbf{3 2 0 0} .\end{array}$ & $\begin{array}{l}.0200 \\
.0207 \\
.0107 \\
.0106 \\
.0208\end{array}$ & $\begin{array}{l}49.2 \\
7.2 \\
62.6 \\
66.8 \\
47.1\end{array}$ & $\begin{array}{l}49.1 \\
72.1 \\
62.5 \\
65.7 \\
47.0\end{array}$ & $\begin{array}{l}24.4 \\
36.8 \\
37.1 \\
26.4 \\
34.6\end{array}$ & $\begin{array}{l}18.0 \\
24.1 \\
17.8 \\
20.5 \\
16.2\end{array}$ \\
\hline $\begin{array}{l}61^{+} \\
82 \\
88 \\
84 \\
86^{+}\end{array}$ & $\begin{array}{l}9.067 \\
28.072 \\
20.668 \\
20.568 \\
63.76\end{array}$ & $\begin{array}{l}56.231 \\
16.188 \\
16.813 \\
16.813 \\
60.44\end{array}$ & $\begin{array}{r}45.760 \\
7.136 \\
12.200 \\
12.100 \\
46.02\end{array}$ & $\begin{array}{r}38.580 \\
7.225 \\
12.206 \\
12.266 \\
37.13\end{array}$ & $\begin{array}{r}10.28 \\
8.27 \\
6.08 \\
6.06 \\
20.64\end{array}$ & $\begin{array}{l}50.019 \\
25.600 \\
20.192 \\
20.201 \\
62.10\end{array}$ & $\begin{array}{r}904.0 \\
1706.0 \\
1600.0 \\
1600.0 \\
976.0\end{array}$ & $\begin{array}{l}3808 . \\
\mathbf{3 5 0 0 .} \\
\mathbf{8 5 0 2 .} \\
\mathbf{3 3 9 2 .} \\
\mathbf{3 4 0 0} \text {. }\end{array}$ & $\begin{array}{l}.0106 \\
.0106 \\
.0205 \\
.0205 \\
.0206\end{array}$ & $\begin{array}{l}5.2 \\
60.2 \\
52.0 \\
50.6 \\
48.2\end{array}$ & $\begin{array}{l}54.1 \\
50.0 \\
0.0 .9 \\
50.4 \\
6.2\end{array}$ & $\begin{array}{l}23.6 \\
39.8 \\
37.6 \\
37.5 \\
22.7\end{array}$ & $\begin{array}{l}20.0 \\
16.6 \\
17.2 \\
17.0 \\
17.7\end{array}$ \\
\hline $\begin{array}{l}86 \\
87 \\
88 \\
89 \\
90\end{array}$ & $\begin{array}{l}17.280 \\
12.484 \\
21.744 \\
13.230 \\
28.206\end{array}$ & $\begin{array}{l}16.018 \\
11.709 \\
20.856 \\
12.242 \\
22.368\end{array}$ & $\begin{array}{r}7.046 \\
8.084 \\
23.907 \\
4.161 \\
17.170\end{array}$ & $\begin{array}{r}8.379 \\
4.561 \\
12.776 \\
4.730 \\
17.504\end{array}$ & $\begin{array}{l}8.80 \\
7.72 \\
8.24 \\
8.26 \\
6.50\end{array}$ & $\begin{array}{l}26.058 \\
12.067 \\
21.300 \\
12.608 \\
22.037\end{array}$ & $\begin{array}{l}1770.0 \\
1920.0 \\
1665.0 \\
1020.0 \\
1600.0\end{array}$ & $\begin{array}{l}3426 . \\
3450 . \\
3466 . \\
3480 . \\
3687 .\end{array}$ & $\begin{array}{l}.0206 \\
.0108 \\
.0108 \\
.0104 \\
.0108\end{array}$ & $\begin{array}{l}71.2 \\
85.2 \\
49.8 \\
57.4 \\
77.8\end{array}$ & $\begin{array}{l}71.0 \\
85.1 \\
49.7 \\
57.3 \\
77.7\end{array}$ & $\begin{array}{l}38.0 \\
42.1 \\
86.5 \\
41.4 \\
85.6\end{array}$ & $\begin{array}{l}23.7 \\
27.5 \\
26.6 \\
28.7 \\
26.8\end{array}$ \\
\hline $\begin{array}{l}91 \\
92 \\
93 \\
94 \\
94 \\
95\end{array}$ & $\begin{array}{l}21.566 \\
41.016 \\
14.462 \\
21.2286 \\
12.168\end{array}$ & $\begin{array}{l}20.466 \\
11.000 \\
13.707 \\
11.570 \\
11.002\end{array}$ & $\begin{array}{c}12.906 \\
34.673 \\
7.08 \\
21.576 \\
6.470\end{array}$ & $\begin{array}{r}18.041 \\
22.031 \\
7.002 \\
11.487 \\
6.605\end{array}$ & $\begin{array}{r}7.94 \\
13.62 \\
7.07 \\
6.20 \\
8.52\end{array}$ & $\begin{array}{l}21.021 \\
42.075 \\
14.008 \\
17.903 \\
11.878\end{array}$ & $\begin{array}{l}2740.0 \\
1616.0 \\
2206.0 \\
2168.0 \\
2480.0\end{array}$ & 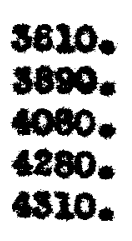 & $\begin{array}{l}.0108 \\
.0101 \\
.0200 \\
.0098 \\
.0000\end{array}$ & $\begin{array}{l}67.5 \\
69.5 \\
86.5 \\
68.5 \\
71.0\end{array}$ & $\begin{array}{l}66.4 \\
69.8 \\
66.4 \\
63.2 \\
70.8\end{array}$ & $\begin{array}{l}36.6 \\
28.1 \\
40.7 \\
38.3 \\
42.2\end{array}$ & $\begin{array}{l}23.0 \\
28.08 \\
21.8 \\
21.1 \\
23.1\end{array}$ \\
\hline $\begin{array}{c}96 \\
97 \\
98 \\
99^{+} \\
200\end{array}$ & $\begin{array}{l}21.620 \\
20.646 \\
21.168 \\
54.65 \\
10.657\end{array}$ & $\begin{array}{l}20.634 \\
10.746 \\
20.367 \\
64.16 \\
10.228\end{array}$ & $\begin{array}{l}14.207 \\
24.027 \\
16.217 \\
16.7 \\
23.796\end{array}$ & $\begin{array}{l}22.974 \\
14.684 \\
24.684 \\
37.1 \\
23.806\end{array}$ & $\begin{array}{r}6.97 \\
6.89 \\
6.77 \\
11.62 \\
6.80\end{array}$ & $\begin{array}{l}22.122 \\
20.246 \\
20.767 \\
58.21 \\
10.392\end{array}$ & $\begin{array}{l}2100.0 \\
2168.0 \\
2168.0 \\
1469.0 \\
2363.0\end{array}$ & $\begin{array}{l}4850 . \\
480 . \\
490 . \\
4600 . \\
4770 .\end{array}$ & $\begin{array}{l}.0009 \\
.0009 \\
.0006 \\
.0006 \\
.0006\end{array}$ & $\begin{array}{l}82.4 \\
88.5 \\
83.0 \\
76.0 \\
60.0\end{array}$ & $\begin{array}{l}81.3 \\
88.4 \\
82.9 \\
76.7 \\
69.9\end{array}$ & $\begin{array}{l}36.0 \\
37.0 \\
86.7 \\
25.0 \\
37.5\end{array}$ & $\begin{array}{l}27.7 \\
30.0 \\
28.2 \\
20.2 \\
20.2\end{array}$ \\
\hline
\end{tabular}




\begin{tabular}{|c|c|c|c|c|c|c|c|c|c|c|c|c|c|}
\hline $\begin{array}{l}\text { Run } \\
\text { No. }\end{array}$ & $\begin{array}{l}\text { Test } \\
\text { Liquid } \\
\text { Inlet }\end{array}$ & $\begin{array}{l}\text { Test } \\
\text { Liquid } \\
\text { Out let }\end{array}$ & $\begin{array}{l}\text { Inlet } \\
\text { Pipe } \\
\text { Temp. }\end{array}$ & $\begin{array}{l}\text { Outlet } \\
\text { Pipe } \\
\text { Temp. }\end{array}$ & $\begin{array}{l}\text { In } \\
\text { Moan } \\
\Delta t\end{array}$ & $\begin{array}{l}\text { Av. } \\
\text { Liquid } \\
\text { Temp. }\end{array}$ & \#/hr & DG & $f$ & $\mathrm{~h}$ & $\frac{h D}{r}$ & $\frac{{ }^{c} \mathrm{p} \mu}{k}$ & $\frac{\frac{h D}{k}}{\left(\frac{p \mu p}{k}\right)}$ \\
\hline $\begin{array}{l}101 \\
102^{+} \\
108^{+} \\
104^{+} \\
105^{*}\end{array}$ & 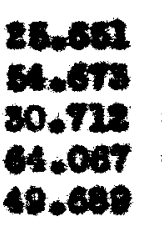 & & $\begin{array}{l}27.821 \\
4.008 \\
22.659 \\
43.755 \\
39.015\end{array}$ & $\begin{array}{l}27.926 \\
4.192 \\
22.57 \% \\
20.477 \\
3.128\end{array}$ & $\begin{array}{c}7.26 \\
15.24 \\
0.208 \\
2.08 \\
11.06\end{array}$ & $\begin{array}{l}25.165 \\
58.052 \\
60.202 \\
62.447 \\
48.045\end{array}$ & $\begin{array}{l}2220.0 \\
1600.0 \\
2160.0 \\
1615.0 \\
1756.0\end{array}$ & $\begin{array}{l}1900 . \\
600 . \\
6000 . \\
5020 . \\
800 .\end{array}$ & $\begin{array}{l}.0004 \\
.0008 \\
.0008 \\
.0002 \\
.0008\end{array}$ & $\begin{array}{l}63.7 \\
61.7 \\
01.6 \\
96.0 \\
86.7\end{array}$ & $\begin{array}{l}28.6 \\
61.6 \\
61.4 \\
94.8 \\
65.6\end{array}$ & $\begin{array}{l}34.4 \\
24.9 \\
32.6 \\
28.0 \\
24.1\end{array}$ & $\begin{array}{l}28.0 \\
28.6 \\
21.6 \\
8 \% .0 \\
32.1\end{array}$ \\
\hline $\begin{array}{l}106 \\
107^{+} \\
108^{+} \\
100^{+} \\
110\end{array}$ & $\begin{array}{l}21.398 \\
80.216 \\
00.316 \\
87.997 \\
8.577\end{array}$ & $\begin{array}{l}20.678 \\
60.608 \\
98.407 \\
65.010 \\
31.428\end{array}$ & $\begin{array}{r}16.294 \\
42.004 \\
40.270 \\
49.865 \\
25.207\end{array}$ & $\begin{array}{l}25.261 \\
33.004 \\
34.719 \\
56.6 \% 0 \\
24.650\end{array}$ & $\begin{array}{c}5.20 \\
13.20 \\
21.06 \\
16.17 \\
7.002\end{array}$ & $\begin{array}{l}21.005 \\
52.001 \\
4.450 \\
58.600 \\
32.000\end{array}$ & $\begin{array}{l}2620.0 \\
1200.0 \\
2020.0 \\
1702.0 \\
2520.0\end{array}$ & $\begin{array}{l}6560 . \\
6720 . \\
6700 . \\
6020 . \\
6080 .\end{array}$ & $\begin{array}{l}.0022 \\
.0020 \\
.0080 \\
.0009 \\
.0008\end{array}$ & $\begin{array}{c}97.4 \\
65.3 \\
87.8 \\
101.0 \\
114.8\end{array}$ & $\begin{array}{l}97.3 \\
65.1 \\
87.6 \\
109.0 \\
114.6\end{array}$ & $\begin{array}{l}26.6 \\
25.4 \\
26.6 \\
24.2 \\
82.9\end{array}$ & $\begin{array}{l}83.1 \\
24.6 \\
32.8 \\
80.7 \\
40.6\end{array}$ \\
\hline $\begin{array}{l}111 \\
118 \\
118 \\
114 \\
125\end{array}$ & $\begin{array}{l}32.488 \\
32.755 \\
30.313 \\
32.178 \\
38.657\end{array}$ & $\begin{array}{l}51.622 \\
31.600 \\
29.534 \\
31.202 \\
22.898\end{array}$ & $\begin{array}{l}25.678 \\
25.728 \\
22.765 \\
25.628 \\
28.147\end{array}$ & $\begin{array}{l}26.201 \\
24.4 \times 8 \\
21.645 \\
25.206 \\
17.848\end{array}$ & $\begin{array}{l}6.488 \\
7.098 \\
7.616 \\
6.228 \\
6.650\end{array}$ & $\begin{array}{l}82.000 \\
32.176 \\
39.625 \\
31.680 \\
28.293\end{array}$ & $\begin{array}{l}2620.0 \\
2565.0 \\
2640.0 \\
2640.0 \\
2800.0\end{array}$ & $\begin{array}{l}6060 . \\
6200 . \\
6180 . \\
6830 . \\
6350 .\end{array}$ & $\begin{array}{l}.0028 \\
.0089 \\
.0008 \\
.0097 \\
.0087\end{array}$ & $\begin{array}{r}107.0 \\
117.0 \\
94.6 \\
117.6 \\
115.0\end{array}$ & $\begin{array}{l}106.9 \\
16.8 \\
94.3 \\
17.8 \\
13.7\end{array}$ & $\begin{array}{l}31.9 \\
81.9 \\
82.7 \\
81.9 \\
85.2\end{array}$ & $\begin{array}{l}37.9 \\
42.4 \\
32.2 \\
41.6 \\
39.1\end{array}$ \\
\hline $\begin{array}{l}116 \\
117 \\
116 \\
119 \\
120\end{array}$ & $\begin{array}{l}89.647 \\
29.658 \\
34.898 \\
31.758 \\
81.263\end{array}$ & $\begin{array}{l}28.724 \\
28.670 \\
38.702 \\
50.069 \\
60.402\end{array}$ & $\begin{array}{l}22.705 \\
28.258 \\
28.948 \\
25.917 \\
25.074\end{array}$ & $\begin{array}{l}22.05 \\
22.008 \\
28.005 \\
25.207 \\
24.040\end{array}$ & $\begin{array}{l}6.772 \\
6.2759 \\
6.795 \\
5.817 \\
5.772\end{array}$ & $\begin{array}{r}29.281 \\
29.114 \\
34.065 \\
51.370 \\
20.770\end{array}$ & $\begin{array}{l}2856.0 \\
2085.0 \\
2780.0 \\
2805.0 \\
4015.0\end{array}$ & $\begin{array}{l}6600 . \\
6000 . \\
6000 . \\
6940 . \\
7210 .\end{array}$ & $\begin{array}{l}.0006 \\
.0085 \\
.0005 \\
.0085 \\
.0005\end{array}$ & $\begin{array}{r}109.2 \\
116.0 \\
90.0 \\
111.0 \\
109.6\end{array}$ & $\begin{array}{l}0.0 \\
115.8 \\
89.6 \\
11.0 \\
00.2\end{array}$ & $\begin{array}{l}32.0 \\
38.0 \\
31.2 \\
82.1 \\
32.6\end{array}$ & $\begin{array}{l}80.2 \\
40.6 \\
48.2 \\
89.2 \\
88.6\end{array}$ \\
\hline $\begin{array}{l}121 \\
122 \\
123 \\
124 \\
125\end{array}$ & $\begin{array}{l}81.080 \\
39.077 \\
80.367 \\
31.428 \\
25.485\end{array}$ & $\begin{array}{l}4.098 \\
32.222 \\
20.002 \\
50.400 \\
28.631\end{array}$ & $\begin{array}{l}26.045 \\
26.080 \\
24.280 \\
25.206 \\
28.000\end{array}$ & $\begin{array}{l}24.040 \\
28.000 \\
28.076 \\
24.041 \\
23.475\end{array}$ & $\begin{array}{l}6.972 \\
6.150 \\
6.327 \\
6.088 \\
6.806\end{array}$ & $\begin{array}{l}31.379 \\
32.000 \\
2.000 \\
30.057 \\
29.005\end{array}$ & $\begin{array}{l}3015.0 \\
3205.0 \\
3160.0 \\
5105.0 \\
3200.0\end{array}$ & $\begin{array}{l}7200 . \\
7300 . \\
7410 . \\
7640 . \\
7810 .\end{array}$ & $\begin{array}{l}.0084 \\
.0084 \\
.0083 \\
.0062 \\
.0082\end{array}$ & $\begin{array}{l}67.6 \\
107.0 \\
104.7 \\
180.2 \\
145.6\end{array}$ & $\begin{array}{l}87.0 \\
06.0 \\
04.5 \\
38.0 \\
43.5\end{array}$ & $\begin{array}{l}32.1 \\
32.6 \\
32.6 \\
52.4 \\
53.0\end{array}$ & $\begin{array}{l}30.8 \\
57.8 \\
36.0 \\
48.6 \\
60.4\end{array}$ \\
\hline
\end{tabular}




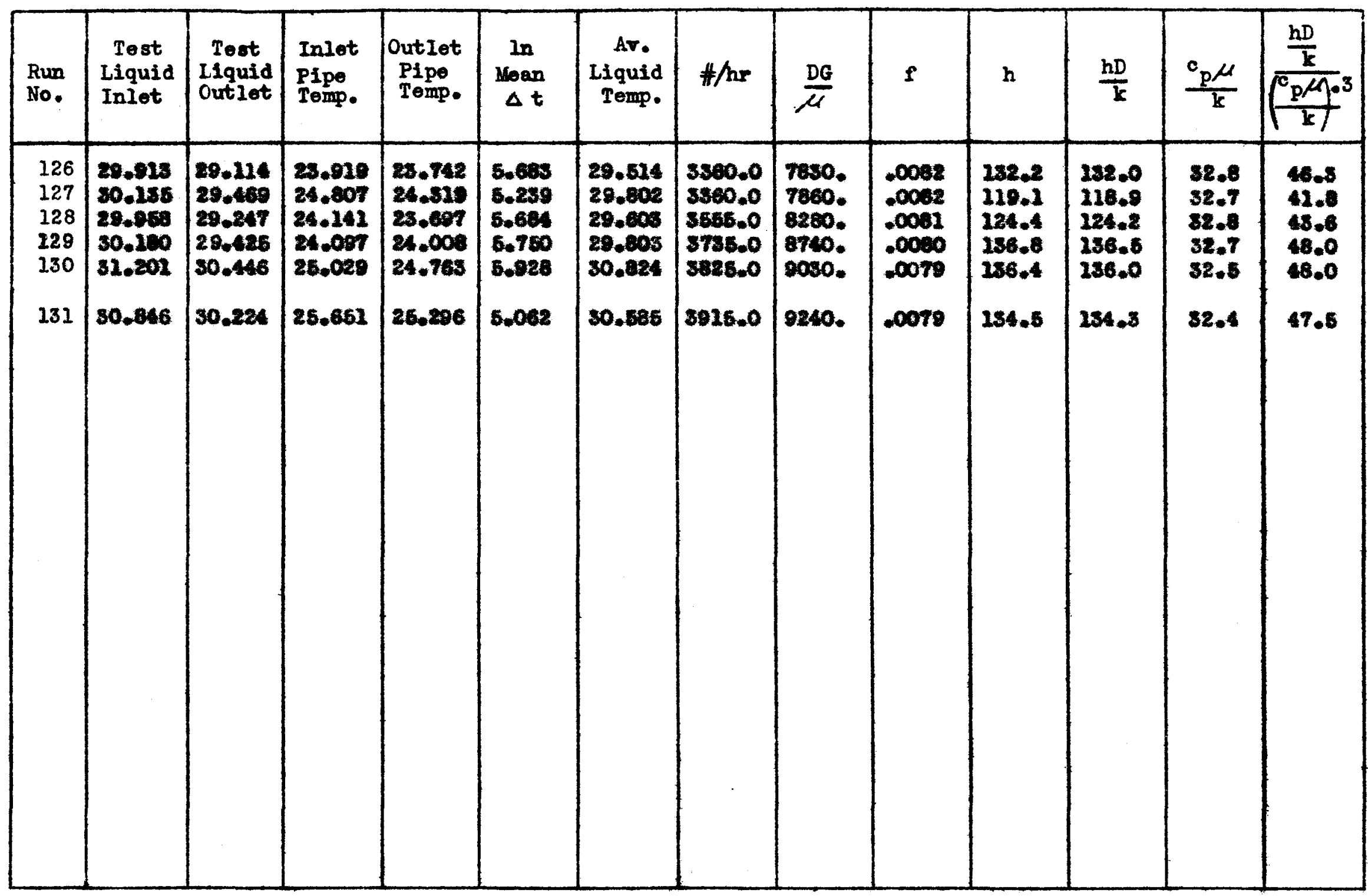




\section{RESULTS AMD CONCLUSIONS}




\section{ERSULA}

and

ConcLosiors

The data obtainod in this invootigation and that of

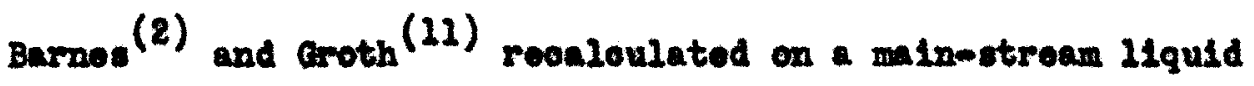
temporature basle were plotted using the equation of Dittus and Boolter.

$$
h=.028 \mathrm{k} / \mathrm{D}(0 \mu / \mathrm{K})^{.3}(\mathrm{D} G / \mu)^{.8}
$$

Where the riscosity is at the f12m oondition, $f$, the exponent of the Prandt 1 group 1: modifled to the .33 powor.

The plot of the oomblined data, Fig. 6, is of the form:

$$
\mathrm{hD} / \mathrm{k} /(0 \mu / \mathrm{k})^{\cdot 3} \mathrm{ras} \mathrm{DQ} / \mu \mathrm{c}
$$

A falr degree of oorrelation in the upper oritical and lower turbulent regions was obtalned. In the lower oritical and riscous reglons the data did not follow the Dittue and Boelter oorrelation. The equation of the line best representing the data through the upper oritloal and lower turbulent rogion wast

$$
h=.01 \mathrm{k} / \mathrm{p}(0 \mu / \mathrm{k})^{.8}(\mathrm{DQ} / \mu)^{.03}
$$

The elope of the 2 ine is oonslatent with the renults of other exporimanters who obtalnod slopes greater than 0.8 for kerosene. Howowe, the values of the coofficlents wore definltaly greater than thos conorally obtalnod. Barnes (2), representing hls data for the ooolint of korosene, proposed the equationt

$$
h=.0387 \mathrm{k} / \mathrm{D}\left(0 \mu_{\mathrm{f}} / \mathrm{k}\right)^{.3}(\mathrm{D} / \mathrm{\mu} / \mu)^{.801}
$$


eraluating the riseosity in the Prandt group at the Plin temperature. These date were eomparable with the date prosented.

The line representing the data in the Vlecous region approaohos a liniting horisontal postion indioating only a -11ght ohange of the hoat transfor opeffiolonts with variation of the Reynolds number. The Iusselt-Prandtl rat10, therefore, 18 substantially independent of the Reynolds number in this regton.

The Dittus and Boelter equation ropresents oor-

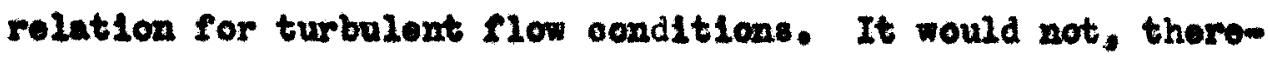
fore, be expeoted to corrolate data in the Nisoous region. This has been pointed out by other invaet igators. A further mbstantiation 18 provided by the new data presonted.

Further oorrelation was attempted plotting the Reynolds number rs. the Husselt number. This correlation, F1G. 7, gave ourres sindlar to those obtalned using the Dittus and Boelter comordinates. The data plotted with $\mathrm{hD} / \mathrm{k}$ as ordinate and Roynolds number as absolssae are slightly more soattered, but the slope of the ourve was subatantially the same.

A modifled friotion faotor ourve. $11_{6}$. 8, was uned in the correlation of the friotion factor and heat tranafer ooexrlelent. A plet of the 1sothermal friotion faotor re, the 


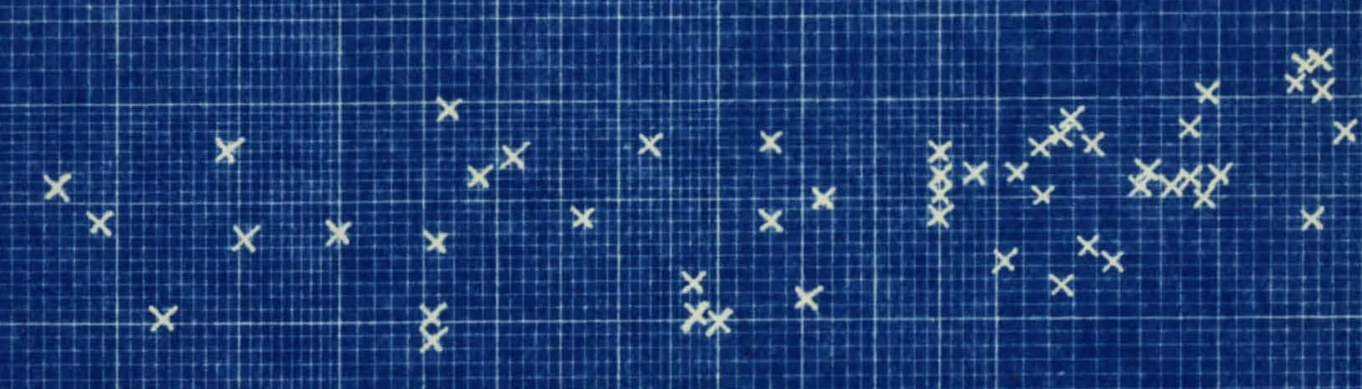
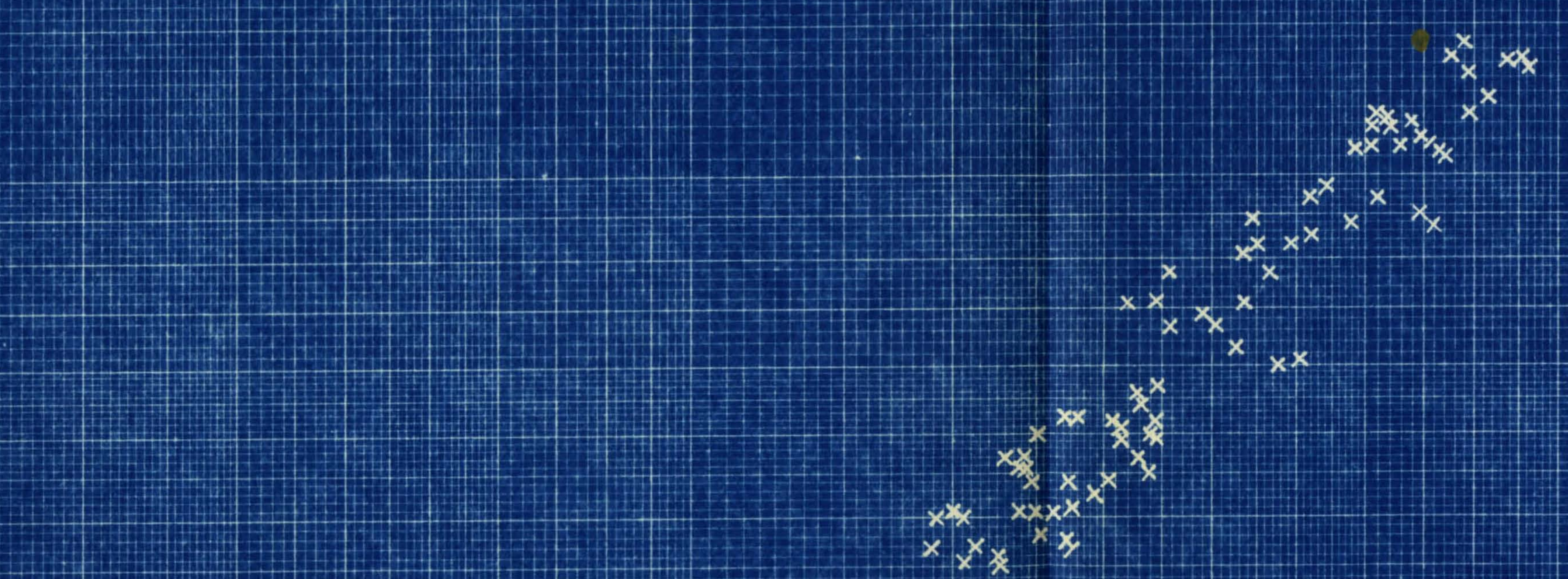

Fig.7- Correlation of Reynolds Number us Nusselt Number for Eocene Data. 


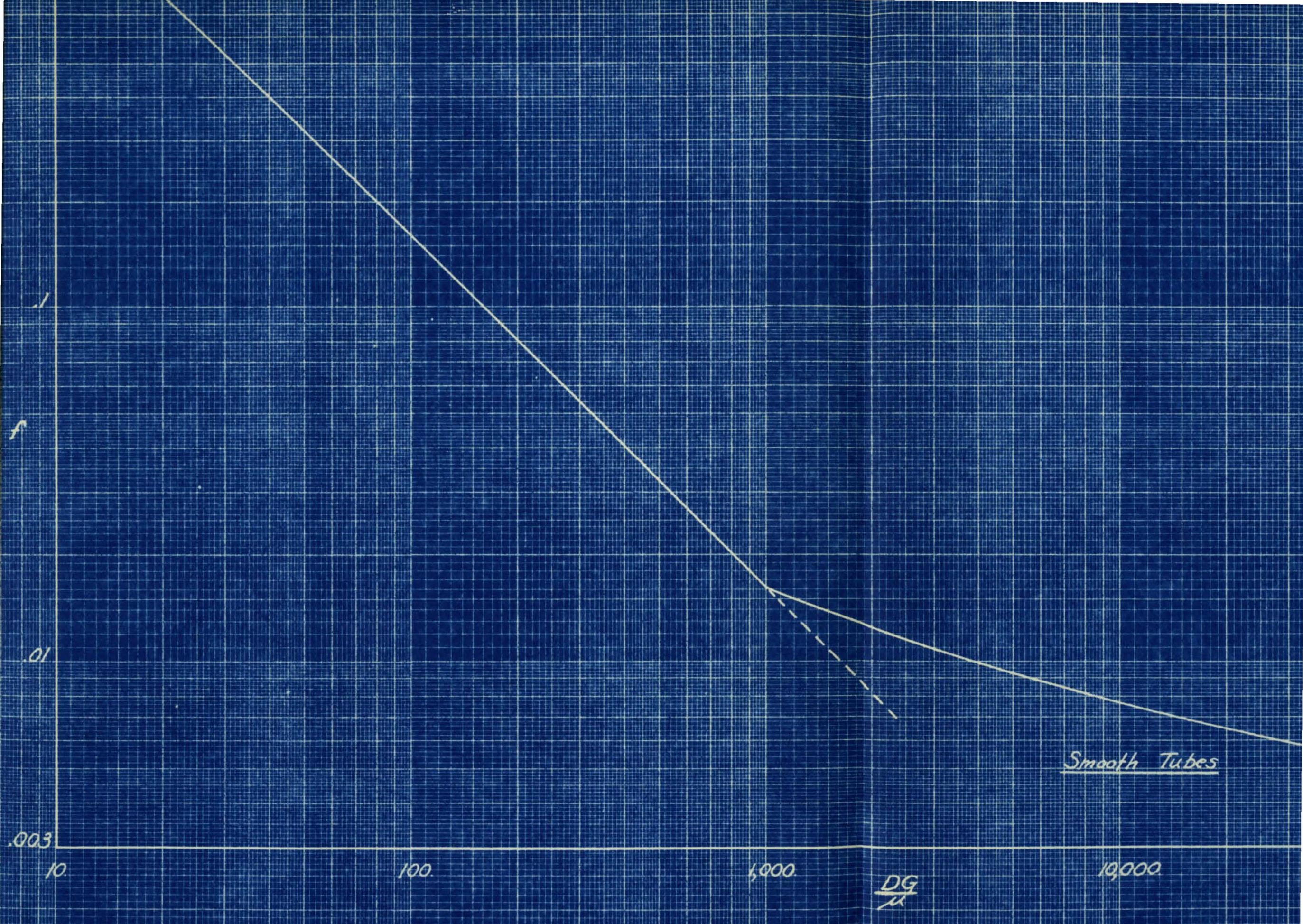

Fig.8 - Friction Foctor ws Rignolds Number. 
Iluesedt group, F1g: 9-11, gave excellent oorrolations for both hoating and oooling. In the turbulent region, FIg. 12 , the hoatlng and oooling ooefflolents were brought together. In the vioove region separate oorroletions for heating and $00011 n$ were obtained. The data through the oritioal region are well dofined.

The correlation of Eorvil and Moddam (16) for the offoot of heating and oooling upon the friotion faotor has been employed. The rolation between the actual and 1 sothermal Irlotion faotor is depondont upon the temperature gradient. The relation of the friotion faotor for heating is given by the equation:

$$
F / t_{h}=1-.00817\left(t_{w}-t\right)
$$

and for cooling:

$$
F / f_{0}=1+.00738\left(t-t_{1}\right)
$$

where $\left(t_{w}-t\right)$ is the temperature drop from tube wall to mainstroam fluid oonditions.

The data in the turbulent region foll in a well-dofinod otralght 2ine. Considering the fact that the ralue of the friotion fuotor is obtalned frem the Reynold number, the date are repreeented by a 1 ine equally well in the plot of $\mathrm{hD} / \mathrm{L} \mathrm{Ts}$. $\mathrm{f}$ or $\mathrm{hD} / \mathrm{x}$ vo. $\mathrm{DO} / \mu$. If the data are oonsiderod as ropresenting an area, the acouracy of the plots are comparable but lightly in favor of the friotion faotor-Iused comordinates. 



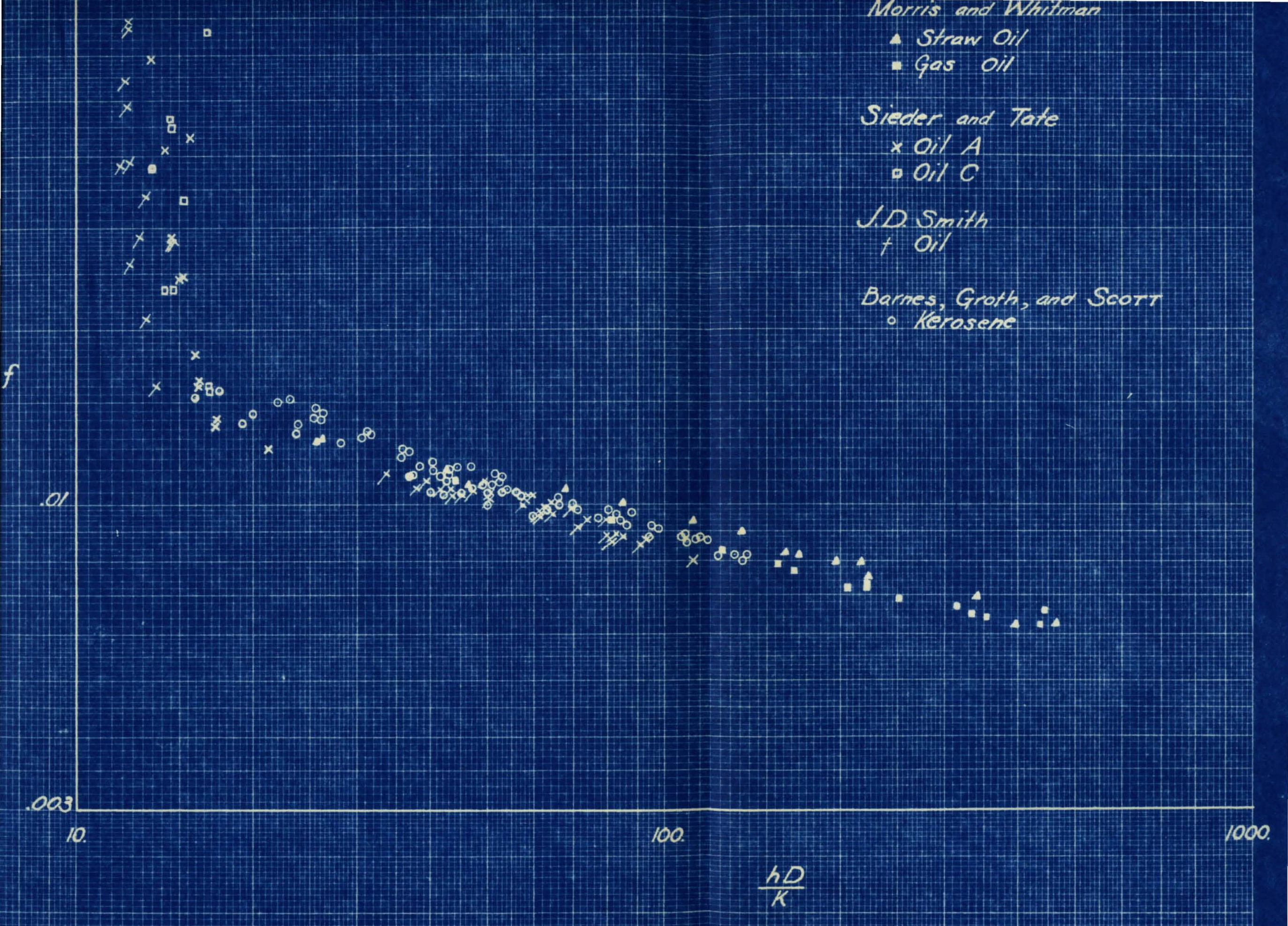

Fig. 10. Cooling Correlation of Friction Factor vs Nessult Number tor Oils. 
Sherwood, kiloy and Mangien

$\times 0 i$ - Length 1150'- Heating

Sherwod and Petrie

7 Kerasend - Heating

10 Suith

- Oil - Heating
- Oil - Cooling

Worris and Whitman

- Gas ol - toating

- Gas oil - cooking

$\triangle$ Straw Oit - Cooling



Bannes, Groth, and Scort

- Kerosene - Cooling

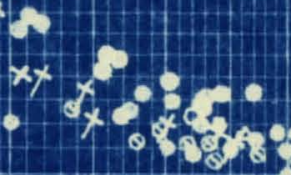

$x_{x} x^{2} 80$

$x^{2} \times x^{2} \times x^{2}=0$

$x^{3} \cos a 0_{0}^{2}$



10.

100.

1000.

$\frac{h D}{k}$

Fiq. 12. - Correlation of Heating and Cooling Caerficients. 
The ohracter of the data in the visooue reglon would Indleate that the Prandt 1 roup whioh Includes the properties of the 11quid oannot be nogleotod. The sleder and tato oorrelation in the riscous region when the Neooslty rat10 1s approximately unity bocomes equiralent to the Dittus and Boelter oorrelation whioh he been shown to be Inadequato. A plot of the friotion factor or Reymolds number va. the Nusselt number provides a far oorrolation for olndlar types of Ilquids in the risoous region and is exoellent in the turbulent reglon.

The otudy of this and other experinontore' date showe that for hoating and oooling the correlation of Dittus and Boelter and sleder and Tato is adequate in the turbulent and uppor oritioal rogion.

A further tudy in the vicoous region for both heatIng and oooling ean woll be ocntinued. 
The author destres to coknowledge the assistanoe of Hims $81 \mathrm{me}$ in odudueting this researoh. 
BIBLIOCRAPHT 
1. Badger, W.L. and MoCabe, W.L. Elements of Chemioel Encinoering, 2d od., Yoarew-HilI Compaw. Yow York. (1938).

2. Barnos, W.R.' Thesis, InIversity of Louisville (1938).

3. Browne, R.Y. and Tinger, F,W, Theals, Univeralty of Loutsvil1e (1985).

4. Colburn, A.P., T.A.I,Ch,E, 29, 174 (1983).

5. Cryder, D.8. and 012111and, E.R., Ind. Eng, Chem,. 24, 1382 (1932).

6. Dittue, F.W. and Boolter, L.K., Untr. Callf. Pub, in Eng., 2. $443(1030)$.

7. Donahew, H; Thosis, Univeralty of Loulsville (2936).

B. Drew, T.B, Ind, Eng. Chom,, 24, 162, (1932).

9. Drow, T, B., Hogan, J.J., and MoAdams, W.H.I Ind, Eng. Chem., 23, 936 (2931).

10. Graets, L., Ann. Physik, 18, 79 (1883), 25, 337 (1885).

12. Groth, I.1 Thesis, Oniversity of Louleville (1937).

12. Hobbard, G.K. and Badger, W.L.3 Ind, Mng. Chem, 5, (Anal.)
$359,(1933)$.

13. Holden, P.B., Thes1, Mas, Inst, Teok. (1927).

14. Jurgensen, D.I.Jr, and Nont11110n, G.H., Ind. Bng, Chom., 27,1466 (1985).

16. Kaye, W.A. and Furnas, C.C.1 Ind, Bng. Chem,. 26, 783 (1934).

16. Keev11, C.S. and Moddams, F.H., Chem, Met, Bng., 36, 464 (2829

17. Kirkbride, C.G. and Uocabe, W.L., Ind. Eng, Chem,, 23, 625 (1831).

18. Lawrenoe, A.E. and Sherwood, T.X.1 Ind. Eng, Chem., 23, 301 (1931). 
19. Lawrenee, A.E, and Hogan, J.J.J Ind, Bng. Chom,, 24, 1318 (1932).

20. MoAdams, W.B., Beat IranumlesLon, Lt od., MoGraw-H111 Company. Hew York (1935).

21. YoAdam, W.E, and Frost, T.H, Ind, Eng, Chem, 13, 13 $(1922), 14,1201$ (1922).

22. Horrit, F.H,I Ind. Bng, Chen, 23, 625 (1931).

23. Norr1s, F.E. and Whitman, W.0.3 Ind, Hog. Chom, 20, 234 (2828).

24. Murphroe, E.V.1 Ind, Eng. Chom, 24, 726 (1932).

25. Nusselt, W.s Itt uber Forsoh., 89 (1910).

26. Prandt 1, L.3 Phya1k. 2., 11, 1072 (1910).

27. Roynolde, 0.1 "Colleoted Work", Vol, II, PP. 535-77, Univeraity Prese (1901).

28. R100, C.W, Ind, Eng, Chem, 16, 460 (1924).

29. Sherwood, T.X. and Petrie, J.M.1 Ind, Ing. Chen., 24, 736 (2982).

30. Shormood, I.X., KLley, D.D., and Mangsen, G.E. Ind, Eng. Cheme. 24, 278 (1938).

31. SLeder, E.X. and Tate, O,B,I Ind. Bng, Chem,, 28, 1428 (1986).

82. Smith, J.D.8 T.A.I.Ch,E., 31, B8 (1985), 588 (1935).

33. WaLker, W.H., LawLe, W.X., Maldams, W.H., and O11111and, B.R.3 Prinoiples of Chomloal nocinoertns, Mocraw-H111 Company. Ion York (1988).

34. White, J.B., Theals, Hass, Inst. Teoh., (1927). 